\title{
Novel classes of non-coding RNAs and cancer
}

\author{
Jiri Sana ${ }^{1,2}$, Petra Faltejskova ${ }^{1,2}$, Marek Svoboda ${ }^{1}$ and Ondrej Slaby ${ }^{1,2,3^{*}}$
}

\begin{abstract}
For the many years, the central dogma of molecular biology has been that RNA functions mainly as an informational intermediate between a DNA sequence and its encoded protein. But one of the great surprises of modern biology was the discovery that protein-coding genes represent less than $2 \%$ of the total genome sequence, and subsequently the fact that at least $90 \%$ of the human genome is actively transcribed. Thus, the human transcriptome was found to be more complex than a collection of protein-coding genes and their splice variants. Although initially argued to be spurious transcriptional noise or accumulated evolutionary debris arising from the early assembly of genes and/or the insertion of mobile genetic elements, recent evidence suggests that the non-coding RNAs (ncRNAs) may play major biological roles in cellular development, physiology and pathologies. NcRNAs could be grouped into two major classes based on the transcript size; small ncRNAs and long ncRNAs. Each of these classes can be further divided, whereas novel subclasses are still being discovered and characterized. Although, in the last years, small ncRNAs called microRNAs were studied most frequently with more than ten thousand hits at PubMed database, recently, evidence has begun to accumulate describing the molecular mechanisms by which a wide range of novel RNA species function, providing insight into their functional roles in cellular biology and in human disease. In this review, we summarize newly discovered classes of ncRNAs, and highlight their functioning in cancer biology and potential usage as biomarkers or therapeutic targets.
\end{abstract}

Keywords: Non-coding RNAs, microRNAs, siRNAs, piRNAs, IncRNAs, Cancer

\section{Introduction}

The abundance of non-translated functional RNAs in the cell has been a textbook truth for decades. Most of these non-coding RNAs (ncRNAs) fulfil essential functions, such as ribosomal RNAs (rRNAs) and transfer RNAs (tRNAs) involved in mRNA translation, small nuclear RNAs (snRNAs) involved in splicing and small nucleolar RNAs (snoRNAs) involved in the modification of rRNAs. The central dogma of molecular biology, developed from the study of simple organisms like Escherichia coli, has been that RNA functions mainly as an informational intermediate between a DNA sequence ('gene') and its encoded protein. The presumption was that most genetic information that specifies biological form and phenotype is expressed as proteins, which have not only diverse catalytic and structural functions, but also regulate the activity of the system in various ways.

\footnotetext{
* Correspondence: on.slaby@gmail.com

'Masaryk Memorial Cancer Institute, Department of Comprehensive Cancer Care, Zluty kopec 7, Brno, Czech Republic, Europe

${ }^{2}$ Central European Institute of Technology, Masaryk University, Brno, Czech Republic, Europe

Full list of author information is available at the end of the article
}

This is largely true in prokaryotes and presumed also to be true in eukaryotes [1]. But one of the great surprises of modern biology was definitely the discovery that the human genome encodes only $\sim 20,000$ protein-coding genes, representing less than $2 \%$ of the total genome sequence (see Figure 1). Subsequently, with the advent of tiling resolution genomic microarrays and whole genome and transcriptome sequencing technologies (ENCODE project) it was determined that at least $90 \%$ of the genome is actively transcribed. The human transcriptome was found to be more complex than a collection of protein-coding genes and their splice variants; showing extensive antisense, overlapping and ncRNA expression $[1,2]$. Although initially argued to be spurious transcriptional noise or accumulated evolutionary debris arising from the early assembly of genes and/or the insertion of mobile genetic elements, recent evidence suggests that the proverbial "dark matter" of the genome may play a major biological role in cellular development, physiology and pathologies. In general, the more complex an organism, the greater is its number of ncRNAs. The enticing possibility that although the number of protein-coding
C Biomed Central

(c) 2012 Sana et al.; licensee BioMed Central Ltd. This is an Open Access article distributed under the terms of the Creative Commons Attribution License (http://creativecommons.org/licenses/by/2.0), which permits unrestricted use, distribution, and reproduction in any medium, provided the original work is properly cited. 


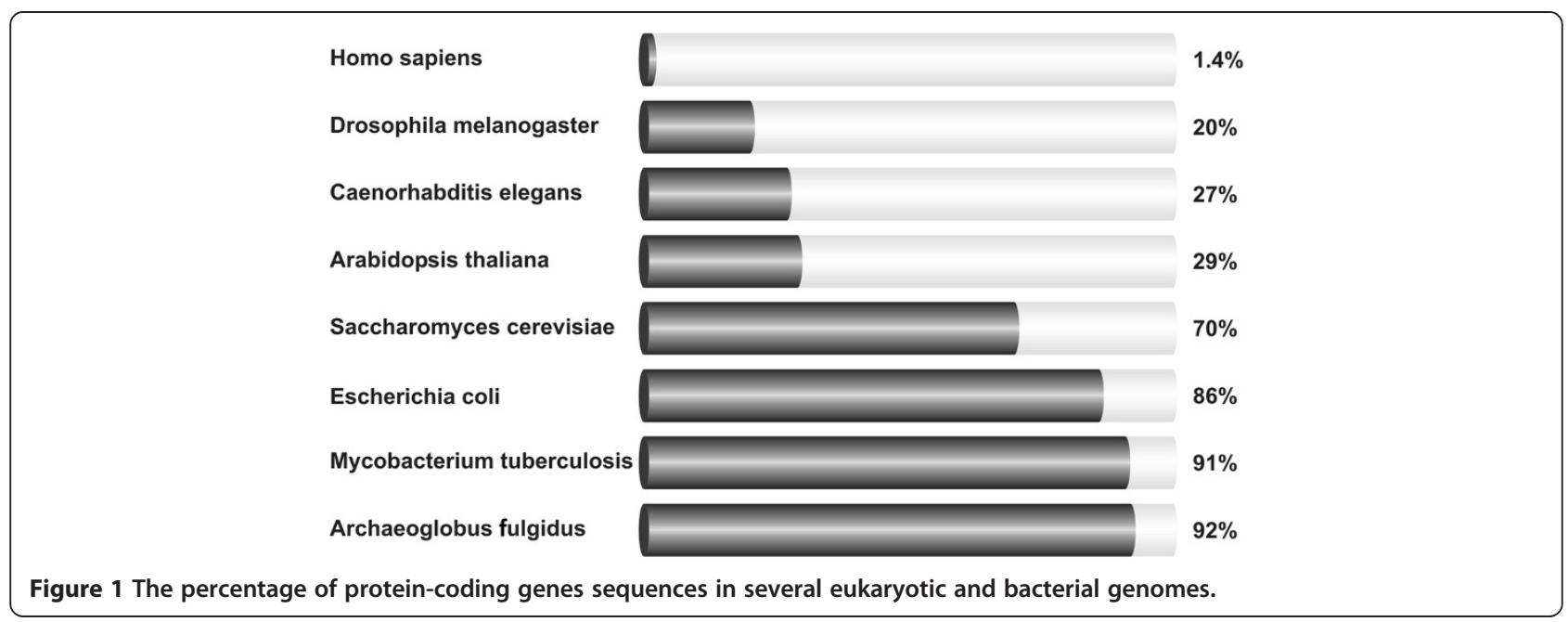

transcripts between organisms is similar, the ultimate control of cellular function may be through interactions between proteins and ncRNA, is corroborated by the fact that the majority of chromatin-modifying complexes do not have DNA binding capacity and therefore, must utilize a third party in binding to DNA. It has been largely demonstrated that this third party may be represented by transcription factors as well as by ncRNAs $[2,3]$.

The beginnings of the present-day understanding on regulatory non-coding RNAs were inspired mainly by the pioneering ideas of John S. Mattick, who has long argued that proteins comprise only a minority of the eukaryotic genome's information output. Considering unique ability of RNA to both fold in three-dimensional space and hybridize in a sequence-specific manner to other nucleic acids, ncRNAs are proposed to behave as a digital-to-analogue processing network, allowing the expansion of complexity in biological systems, well beyond purely protein-based regulatory networks [4].

Non-coding RNAs are grouped into two major classes based on transcript size; small ncRNAs and long ncRNAs (lncRNAs) (classification of recently discovered non-coding RNAs is summarized in Table 1). Small ncRNAs are represented by a broad range of known and newly discovered RNA species, with many being associated with $5^{\prime}$ or $3^{\prime}$ regions of protein-coding genes. This class includes the well-documented miRNAs, siRNAs, piRNAs, etc. Most of them significantly extended our view of molecular carcinogenesis, and at present they are subject of intensive translational research in this field. In contrast to miRNAs, lncRNAs are mRNA-like transcripts ranging in length from $200 \mathrm{nt}$ to 100 kilobases $(\mathrm{kb})$ and lacking significant open reading frames. LncRNAs' expression levels appear to be lower than protein-coding genes, and some lncRNAs are preferentially expressed in specific tissues. The small number of characterized human lncRNAs have been associated with a spectrum of biological processes including alternative splicing or nuclear import. Moreover they can serve as structural components, precursors to small RNAs and even as regulators of mRNA decay. Furthermore, accumulating reports of misregulated lncRNA (HOTAIR, MALAT1, HULC, T-UCRs, etc.) expressions across numerous cancer types suggest that aberrant lncRNA expression may be an important contributor to tumorigenesis. In this review, we summarize recent knowledge of novel classes of ncRNAs, their biology and function, with special focus on their significance in cancer biology and oncology translational research, which is the field where the number of publications focusing this topic is rapidly growing [5-7].

\section{Small non-coding RNAs}

Post-transcriptional RNA silencing or RNA interference (RNAi) is a naturally conserved mechanism of regulation of gene expression described in almost all eukaryotic species including humans $[8,9]$. It is mostly triggered by dsRNA precursors that vary in length and origin. These dsRNAs are rapidly processed into short RNA duplexes subsequently generating small ncRNAs (small ncRNAs), which are associated with Argonaute family proteins and guide the recognition and ultimately the cleavage or translational repression of complementary singlestranded RNAs, such as messenger RNAs or viral genomic/antigenomic RNAs. Moreover, the small ncRNAs have also been implicated in guiding chromatin modifications $[9,10]$. Since the discovery of the first small ncRNA, various classes of small ncRNAs have been identified. Based on whether their biogenesis is dependent on Dicer, the dsRNA specific RNA III ribonuclease, all the known eukaryotic small ncRNAs can be classified into two goups: Dicer-dependent, such as microRNAs (miRNAs), small interfering RNAs (siRNAs), and in some cases small nucleolar RNAs (snoRNAs); and 
Table 1 Types of recently discovered human non-coding RNAs

\begin{tabular}{llll}
\hline \multicolumn{1}{c}{ Class } & Symbol & Characteristic \\
\hline $\begin{array}{l}\text { Small } \\
\text { non-coding } \\
\text { RNAs }\end{array}$ & MicroRNAs & miRNAs & $\begin{array}{l}18-25 \mathrm{nt} \text {; account 1-2\% of the human genome; } \\
\text { control the } 50 \% \text { of protein-coding genes; guide } \\
\text { suppression of translation; Drosha and Dicer } \\
\text { dependent small ncRNAs }\end{array}$ \\
& $\begin{array}{lll}\text { Small interfering } \\
\text { RNAs }\end{array}$ & siRNAs & $\begin{array}{l}19-23 \mathrm{nt} \text {; made by Dicer processing; guide } \\
\text { sequence specific degradation of target mRNA }\end{array}$
\end{tabular}

Piwi-interacting piRNAs 26-30 nt; bind Piwi proteins; Dicer independent; RNAs

Small nucleolar

RNAs

Promoter-
associated small
RNAs

Transcription initiation RNAs

Centromere repeat associated small interacting RNAs

Telomere-specific small RNAs

Pyknons

\section{Long Long intergenic non-coding non-coding RNAs} RNAs

Long intronic noncoding RNAs

Telomere-associated ncRNAs

Long non-coding

RNAs with dual functions

Pseudogene RNAs

Transcribed-
ultraconserved
regions

Transcribed-
ultraconserved regions exist in genome clusters; principally restricted to the germline and somatic cells bordering the germline

snoRNAs 60-300 nt; enriched in the nucleolus; in vertebrate are excised from pre-mRNA introns; bind snoRNP proteins

PASRs 20-200 nt; modified 5' (capped) ends; coincide with the transcriptional start sites of protein- and non-coding genes; made from transcription of short capped transcripts

tiRNAs $\sim 18 \mathrm{nt}$; have the highest density just downstream of transcriptional start sites; show patterns of positional conservation; preferentially located in GC-rich promoters

crasiRNAs $34-42 \mathrm{nt}$; processed from long dsRNAs

tel-sRNAs 24 nt; Dicer independent; 2'-O-methylated at the 3 ' terminus; evolutionarily conserved from protozoa to mammals; have not been described in human up to now

subset of patterns of variable length; form mosaics in untranslated and protein-coding regions; more frequently in $3^{\prime}$ UTR

lincRNAs

ranging from several hundreds to tens of thousands nts; lie within the genomic intervals between two genes; transcriptional cis-regulation of neighbouring genes

lie within the introns; evolutionary conserved; tissue and subcellular expression specified

100 bp - >9 kb; conserved among eukaryotes; synthesized from C-rich strand; polyadenylated; form inter-molecular G-quadruplex structure with single-stranded telomeric DNA

both protein-coding and functionally regulatory RNA capacity

gene copies that have lost the ability to code for a protein; potential to regulate their proteincoding cousin; made through retrotrans-position; tissue specific

T-UCRS

longer than 200 bp; absolutely conserved between orthologous regions of human, rat, and mouse; located in both intra- and intergenic regions
Disease / biological function associations

initiation of various disorders including many, if not all, cancers / regulation of proliferation, differentiation, and apoptosis involved in human development

great potential in diseases treatment / posttranscriptional gene silencing mainly through RISC degradation mechanism; defence against pathogenic nucleic acids

relationship between piRNAs and diseases has not yet been discovered / involved in germ cell development, stem self-renewal, and retrotransposon silencing

association with development of some cancers / important function in the maturation of other non-coding RNAs, above all, rRNAs and snRNAs; miRNA-like snoRNAs regulate mRNAs

relationship with diseases has not yet been discovered / involved in the regulation of the transcription of protein-coding genes by targeting epigenetic silencing complexes

relationship between crasiRNAs and diseases has not yet been discovered / involved in the recruitment of heterochromatin and/or centromeric proteins

relationship between tel-sRNAs and diseases has not yet been discovered / epigenetic regulation

expected association with cancer biology / possible link with posttranscriptional silencing of genes, mainly involved in cell communication, regulation of transcription, signaling, transport, etc.

involved in tumorigenesis and cancer metastasis / involved in diverse biological processes such as dosage compensation and/or imprinting

aberrantly expressed in human cancers / possible link with posttranscriptional gene silencing

possible impact on telomere-associated diseases including many cancers / negative regulation of telomere length and activity through inhibition of telomerase

deregulation has been described in breast and ovarian tumors / modulate gene expression through diverse mechanisms

often deregulated during tumorigenesis and cancer progression / regulation of tumor suppressors and oncogenes by acting as microRNA decoys

expression is often altered in some cancers; possible involvement in tumorigenesis / antisense inhibitors for protein-coding genes or other ncRNAs 
Dicer-independent small ncRNAs, such as PIWIinteracting RNAs (piRNAs) [11] (Figure 2). Moreover, phylogenetic analysis indicates that known Argonaute family proteins can be divided into two subgroups namely AGO based on AGO1 and PIWI based on PIWI. Interestingly, Ago proteins interact with miRNAs and siRNAs while Piwi subgroup is characterized by interaction with piRNAs [12]. Biogenesis of other small non-coding RNAs is less or completely undescribed yet. These RNAs are generally classified according to their genome and function localization. Among them belong promoterassociated small RNAs (PASRs), transcription initiation RNAs (tiRNAs), centromere repeat associated small interacting RNAs (crasiRNAs), and telomere-specific small RNAs (tel-sRNAs). To the class of small non-coding RNAs also belong the recently discovered pyknons that, as suggested by current findings, are involved in many biological functions. It was many times described that some of above mentioned small non-coding RNAs play important roles in pathogenesis of various diseases including tumors. In this respect, the most studied ncRNAs are miRNAs, which have been described in many, if not all, cancers [13-16].

\section{MicroRNAs}

The most frequently studied subclass of small ncRNAs are microRNAs (miRNAs), originally discovered by Victor Ambros in Caenorhabditis elegans. They are 18-25 nucleotides long, evolutionary conserved, single-stranded
RNA molecules involved in specific regulation of gene expression in eukaryotes [17]. It is predicted that miRNA genes account for $1-2 \%$ of the human genome and control the activity of $\sim 50 \%$ of all protein-coding genes $[18,19]$. Early annotation for the genomic position of miRNAs indicated that most miRNAs are located in intergenic regions ( $>1 \mathrm{~kb}$ away from annotated or predicted genes), although a sizeable minority was found in the intronic regions of known genes in the sense or antisense orientation. This led to the postulation that most miRNA genes are transcribed as autonomous transcription units [19]. A detailed analysis of miRNA gene expression showed that miRNA genes can be transcribed from their own promoters and that miRNAs are generated by RNA polymerase II (RNAPII) as primary transcripts (pri-miRNAs). These are processed to short 70-nucleotide stem-loop structures known as pre-miRNAs by the ribonuclease called Drosha and the double-stranded-RNA-binding protein known as Pasha (or DGCR8 - DiGeorge critical region 8), which together compose a multiprotein complex termed a microprocessor. The pre-miRNAs are transported to cytoplasm by the RAN GTP-dependent transporter exportin 5 (XPO5). In the cytoplasm, the pre-miRNAs are processed to mature miRNA duplexes by their interaction with the endonuclease enzyme Dicer in complex with dsRNA binding protein TRBP $[19,20]$. One strand ("guide strand") of the resulting 18-25-nucleotide mature miRNA duplex ultimately gets integrated into the miRNA-induced silencing complex (miRISC) with the

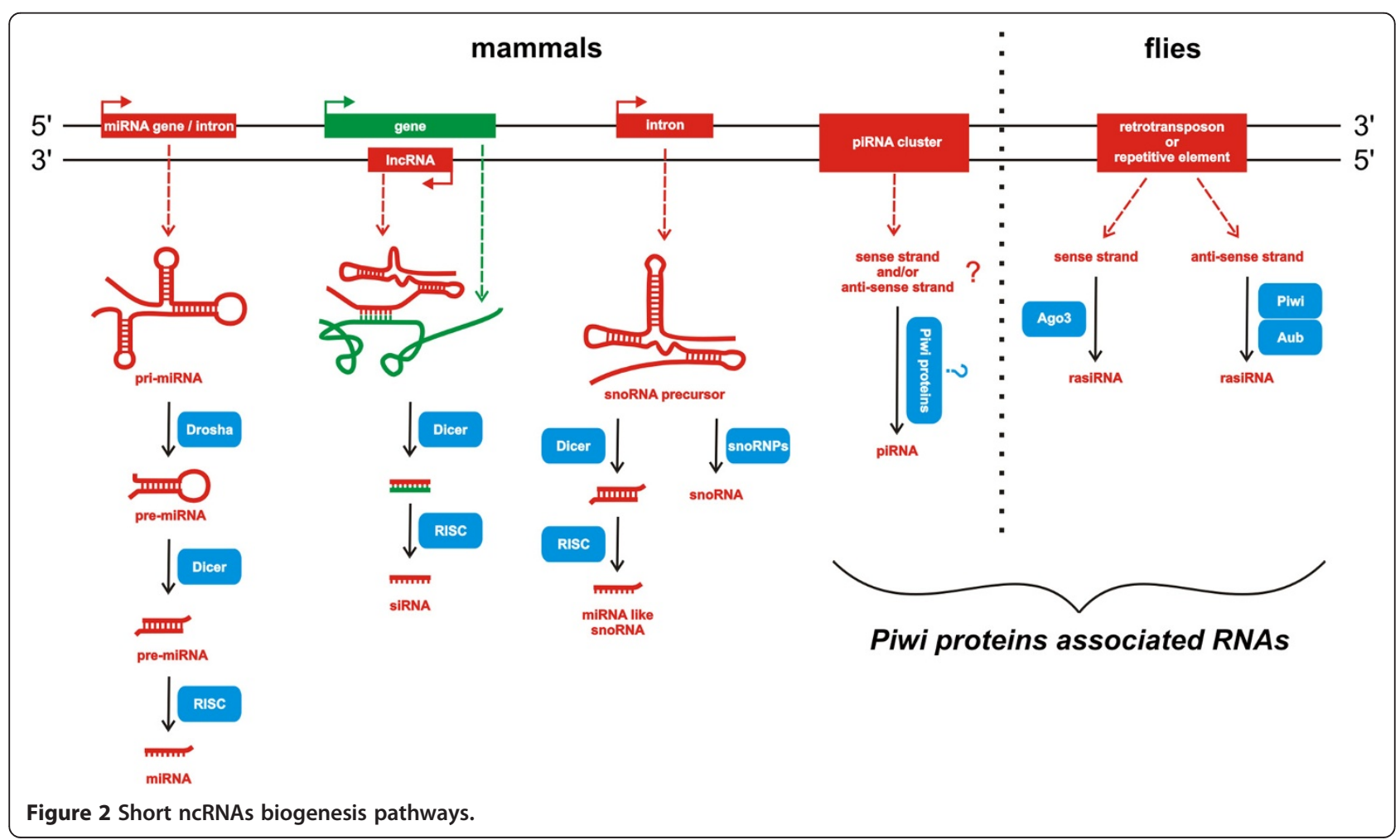


central part formed by proteins of the Argonaute family, whereas the other strand (passenger or miRNA*) is released and degraded. The retained ("guide") strand is the one that has the less stably base-paired $5^{\prime}$ end in the miRNA/miRNA* duplex. Generally, most miRNA genes produce one dominant miRNA species. However, the ratio of miRNA to miRNA* can vary in different tissues or developmental stages, which probably depends on specific properties of the pre-miRNA or miRNA duplex, or on the activity of different accessory processing factors [19]. Moreover, the ratio might be modulated by the availability of mRNA targets as a result of enhanced destabilization of either miRNA or miRNA* occurring in the absence of respective complementary mRNAs [20]. Mature miRNAs in miRISC exert their regulatory effects by binding to imperfect complementary sites. MiRNAs repress target-gene expression post-transcriptionally, apparently at the level of translation, through a miRISC complex that is similar to, or possibly identical with, that used for the RNAi pathway discussed later. Perfect complementarity of mRNA-miRNA allows Ago-catalyzed cleavage of the mRNA strand, whereas central mismatches exclude cleavage and promote repression of mRNA translation. Consistent with translational control, miRNAs that use this mechanism reduce the protein levels of their target genes, but the mRNA levels of these genes are barely affected [21-23]. Current studies indicate that miRNA targeting in mammalian cells occurs predominantly through binding to sequences within 3'UTRs [24,25], however inhibition of gene expression through targeting the 5'UTR has been also demonstrated [26]. Nevertheless, statistical analyses of conserved miRNA target sequences proved that mammalian miRNA target sites rarely occur within 5'UTRs $[24,25,27]$. Moreover, it was found out that miR-10a induces, rather than inhibits, protein expression through binding to 5'UTRs of cellular transcripts [23]. It is therefore supposed that binding to $5^{\prime}$ UTR results in mechanistic effects divergent from 3'UTR binding.

Most of the miRNAs described to date regulate crucial cell processes such as proliferation, differentiation, and apoptosis. Therefore, these RNAs are involved in human development as well as in initiation of various disorders including many, if not all, cancers where miRNAs have been found to be also significant prognostic and predictive markers [13,28-35]. Examples of miRNAs with significant functional effects in cancer are mentioned below.

Bloomston et al. [36] identified 6 miRNAs linked to long-term survival in pancreatic adenocarcinoma. They found also that expression level of miR-196a-2 was able to predict patients' survival, since higher miRNA levels marked the poor survivors group. In HCC, up-regulation of miR-221 and down-regulation of
miR-122 were associated with shorter time to recurrence $[37,38]$. MiR-21 is up-regulated in many solid tumors, including CRC. Slabý et al. [39] proved that miR-21 over-expression shows a strong correlation with the established prognostic factors as nodal stage, metastatic disease and UICC stage. Moreover, Kulda et al. [40] correlated miR-21 expression to disease-free interval (DFI). There was shorter DFI in patients with a higher expression of miR-21. Several studies proved that down-regulated expression of miR-221, miR-137, miR372 , miR-182\%, let-7 and miR-34a is associated with shorter survival in patients with lung cancer [41-43]. Breast cancer metastatic process has been connected with up-regulation of miR-10b [44] and with loss of expression of miR-126 and miR-335 [45]. Finally, higher levels of miR-15b were associated with poor survival and recurrence in melanoma [46]. Another important question for management of cancer patients is the possibility of predicting therapy response. Nakajima et al. [47] identified let-7g and miR-181b as significant indicators for chemoresponse to S-1-based chemotherapy. The same year, Markou et al. [48] demonstrated that inhibition of miR-21 and miR-200b increases the sensitivity of cholangiocarcinoma cells to gemcitabine. Yang et al. [49] identified miR-214, a miRNA up-regulated in ovarian cancer, as responsible of cisplatin resistance through its action on PTEN/AKT pathway. Subsequently, there is a large number of publications which confirmed many 3'UTRs of oncogenes an tumor suppressor genes to be direct targets of selected miRNAs. According to a recent study by Nagel et al. [50], miR-135a and miR-135b decrease translation of the APC transcript in vitro. Concerning CRC, KRAS oncogene has been reported to be a direct target of the let-7 miRNA [51]. Another miRNA associated with KRAS regulation is miR-143 [52]. MiRNAs arrays-based studies revealed the $\mathrm{p} 85 \beta$ regulatory subunit of PI3K as a direct target of miR-126 [53]. Moreover, another important regulatory component of PI3K pathway, the tumor suppressor gene PTEN, is strongly repressed by miR-21 in hepatocellular carcinoma [54]. MiR-17-5p belongs to a highly conserved, polycistronic miRNA cluster miR-17-92. Yu et al. [55] described the function of this cluster as a negative regulator of cell cycle and proliferation of human breast cancer cells, which directly regulates cyclin D1 (CCND1). The same cluster is also involved in malignancies of B cell origin [56] and a direct regulation by CMYC has been reported $[57,58]$. Some of the most often deregulated miRNAs with their experimentally proved mRNA targets are summarized in the Table 2, however, the number of described miRNAs and putative targets is much more higher and it is not possible to mention all of them. 
Table 2 Gene targets of the most common described human cancer-associated miRNAs

\begin{tabular}{cc}
\hline MiRNA & Associated cancers \\
\hline MiR-21 & CRC, PC, RCC, GBM, BrC, \\
& NSCLC, BCL, PTC, HCC, \\
& HNSCC, ESCC, GC, CML, \\
& CCC, MM, OC, M, LC, PDA \\
& \\
MiR-155 & NSCLC, SCLC, HCC, BrC, \\
& M, CCC, HL, PDA, RCC, \\
& GBM, PTC, CML, CRC, \\
& SPA, AML, NPC, CLL
\end{tabular}

MiR-145 BrC, CRC, ESCC, NSCLC, PC, $\mathrm{BCL}, \mathrm{OC}, \mathrm{GC}, \mathrm{BIC}, \mathrm{NPC}, \mathrm{HCC}$

MiR-221 BrC, PC, CRC, M, GBM, ALL, MiR-222 HCC, PTC, PDA, GC, CML, $N S C L C, A M L, O C$

Let-7a $\quad \mathrm{M}, \mathrm{HL}, \mathrm{nHL}, \mathrm{CRC}, \mathrm{SLC}, \mathrm{NSCLC}$ GC, HNSCC, ESCC, OC, CLL, $\mathrm{HCC}$

MiR-16 LC, OC, NPC, GC, PC, BrC, $\mathrm{HCC}, \mathrm{MM}, \mathrm{CLL}, \mathrm{HL}$

MiR-200 BrC, PDA, GC, HNSCC, M, OC, PC

MiR-205 M, BrC, PC, ESCC, HNSCC

MiR-31 PTC, CRC, BrC, LC, GC, HCC

MiR-126 CRC, GC, BrC, SCLC, AML, $\mathrm{NSCLC}, \mathrm{HCC}$

MiR-210 PDA, RCC, BrC, PC, GBM NSCLC, OC, GC, HNSCC

MiR-9 GBM, PC, nHL, EC, OC

MiR-141 PC, EC, CRC, HNSCC, LC $\mathrm{BrC}, \mathrm{ESCC}, \mathrm{OC}, \mathrm{RCC}$

MiR-122 HCC, RCC

In vitro confirmed gene targets

PDCD4, TIMP3, RhoB, Spry1, PTEN, TM1, CDK2AP1, ANP32A, SMARCA4,

ANKRD46, THRB, Cdc25A, BMPRRII, LRRFIP1, BTG2, MARCKS, TPM1

FOXO3A, SOX6, SATB1, SKI, Wee1, SOCS1, SHIP1, S/EBP IFN- $\gamma$ Ra, AGTR1, FGF7, ZNF537, ZIC3, IKBKE, RhoA BACH1, ZIC3, HIVEP2, CEBPB, ZNF652, ARID2, SMAD5, TP53INP1

c-Myc, ERK5, FSCN1, SMAD2/3, IGF-1R, FLI1, DFF45, mucin 1, MYO6, CBFB, PPP3CA, CLINT1, ICP4, RTKN

DVL2, KIT, CDKN1B, Bmf, p27, HOXB5, CDKN1C/p57, CDKN1B/p27, MMP1, SOD2, TIMP3, Dicer1, ERa, ARHI, PUMA, p27Kip1, p57

PRDM-1, STAT3, Caspase-3, Integrin $\beta 3$, PRDM1/blimp-

VEGFR2, FGFR1, Zyxin, Cyclin E1, Bmi-1, BRCA-1, BCL2

FN1, MSN, NTRK2, LEPR, ARHGAP19, ZEB1/2, Flt1/ VEGFR1, FAP-1, FOG2, ERRFI-1

Runx2, E2F1, ErbB3, Zeb1

LATS2, WAVE3, SATB2, ITGA5 RDX, RhoA, FIH

SLC7A5, SOX2, PLAC1, VEGFA, PIK3R2, Crk, EGFL7, p85beta

FGFRL1, SDHD, MNT

CAMTA1, PDGFR- $\beta$, CDX2, PRDM-1, E-cadherin, NFkappaB1

SIP1, YAP1

BCl-w, ADAM17

CRC colorectal cancer, PC prostate cancer, RCC renal cell carcinoma, GBM glioblastoma multiforme, BrC breast cancer, LC lung cancer, NSCLC non-smal cell lung cancer, SCLC small cell lung cancer, BCL B-cell lymphoma, PTC papillary thyroid carcinoma, HCC hepatocellular carcinoma, HNSCC head and neck squamous cell carcinoma, ESCC esophagus squamous cell carcinoma, GC gastric cancer, CLL chronic lymphocytic leukemia, CML chronic myelogenous leukemia, ALL acute lymphocytic leukemia, AML acute myeloid leukemia, CCC cervical cell carcinoma, MM multiple myeloma, OC ovarian cancer, $\mathrm{M}$ melanoma, LC laryngeal carcinoma, PDA pancreatic ductal adenocarcinoma, HL Hodgkin lymphoma, nHL Non-Hodgkin lymphoma, SPA sporadic pituitary adenomas, NPC nasopharyngeal carcinoma, BIC bladder cancer, EC endometrial cancer.

\section{Small interfering RNAs}

Another class of small ncRNAs involved in posttranscriptional RNA silencing are so-called small interfering RNAs (siRNAs). They are produced from long dsRNAs of exogenous or endogenous origin [59]. These short helical RNA molecules are formed by two at least partially complementary RNA single strands, namely the passenger strand and the guide strand. Typical strand lengths of these dsRNAs are 19-23 nucleotides and they are made by Dicer processing as miRNAs [60]. One of the arisen single strands is subsequently incorporated into RISC (RNA-induced silencing complex) where guides sequence-specific degradation of complementary target mRNAs unlike miRNA that rather suppresses translation and does not lead to degradation of the mRNA target $[9,61,62]$. SiRNAs are worldwide used in gene silencing experiments and have become a specific and powerful tool to turn off the expression of target genes, and also turned into a promising experimental tool in molecular oncology. SiRNAs could be used in cancer therapy by several strategies. These include the suppression of overexpressed oncogenes, retarding cell division by interfering with cyclins and related genes or enhancing apoptosis by inhibiting anti-apoptotic genes. For example, Vassilev et al. [63] developed new siRNAbased inhibitors of the p53-MDM2 protein interaction. A year later, Wu et al. [30] demonstrated that downregulation of RPL6 (ribosomal protein L6) in gastric cancer SGC7901 and AGS cell lines by siRNA reduced colony forming ability and cell growth. Moreover, the cell cycle of these cells was suppressed in G1 phase. Similarly, CDK8 specific siRNA transfection down-regulated the expression of CDK8 in colon cancer cells, which was also associated with a decrease in the expression of $\beta$ catenin, inhibition of proliferation, increased apoptosis and G0/G1 cell cycle arrest [64]. Dufort et al. [65] described that cell transfection of IGF-IR siRNAs decreased proliferation, diminished phosphorylation of downstream signaling pathway proteins, AKT and ERK, and caused a G0/G1 cell cycle block in two murine breast cancer cell lines, EMT6 and C4HD. The IGF-IR silencing also induced secretion of two proinflammatory cytokines, TNF- $\alpha$ and IFN- $\gamma$. Another study showed that mTOR-siRNA transfection significantly inhibits cell proliferation, increases the level of apoptosis and decreases migration of NSCLC cells, and could be used as an alternative therapy targeting mTOR with fewer side effects [66]. RNAi against multidrug resistance genes or chemoradioresistance and angiogenesis targets may also provide beneficial cancer treatments. He et al. [67] proved that silencing of MDR1 by siRNA led to decreased P-glycoprotein activity and lower drug resistance of L2-RAC cells, which could be used as a novel approach of combined gene and chemotherapy for yolk 
sac carcinoma. Another study showed that combination of proteasome inhibitors with Mcl-1 siRNA enhances the ultimate anticancer effect in DLD-1, LOVO, SW620, HCT-116, SKOV3 and H1299 cell lines [68]. Bansal et al. [69] states that selective siRNA depletion of CDK1 increases sensitivity of patients with ovarian cancer to cisplatin-induced apoptosis. The number of publications dealing with siRNAs is rapidly growing and successful cancer therapy by siRNA in vitro and in vivo provides the enthusiasm for potential therapeutic applications of this technique [70]. Some examples of siRNA cancer therapies in clinical trials are summarized in Table 3.

\section{Piwi proteins associated RNAs}

Extensive research in the past few years has revealed that members of the Argonaute protein family are key players in gene-silencing pathways guided by small RNAs. This family is further divided into AGO and PIWI subfamilies [72]. It was proved that the AGO proteins are present in diverse tissues and bind to miRNAs and siRNAs, whereas PIWI proteins are especially present in germline, and associate with a new class of small ncRNAs termed PIWI-interaction RNAs (piRNAs). PiRNAs are typically 24-32 nucleotides long RNAs that are generated by a Dicer-independent mechanism. It was thought that they are derived only from transposons and other repeated sequence elements [73] and therefore, they were alternatively designated as repeat-associated small interfering RNAs (rasiRNAs) [74]. But it is now clear that piRNAs can be also derived from complex DNA

Table 3 Small RNA-based therapeutics in clinical trials (adapted from [71])

\begin{tabular}{|c|c|c|c|c|}
\hline Gene target & Drug type & Drug name & $\begin{array}{l}\text { Clinical } \\
\text { phase }\end{array}$ & Notes \\
\hline$\overline{B C l}-2$ & LNA-oligo & SPC2996 & $|/| \mid$ & $\mathrm{CLL}$ \\
\hline $\begin{array}{l}\text { Immunoproteasome } \\
\beta \text {-subunits LMP2, } \\
\text { LMP7 and MECL1 }\end{array}$ & siRNA & $\begin{array}{l}\text { Proteasome } \\
\text { siRNA }\end{array}$ & I & $\begin{array}{l}\text { Metastatic } \\
\text { lymphoma }\end{array}$ \\
\hline PLK1 & siRNA & PLK SNALP & $\begin{array}{l}\text { pre- } \\
\text { clinical }\end{array}$ & \\
\hline $\begin{array}{l}\text { M2 subunit of } \\
\text { ribonucleotide } \\
\text { reductase }\end{array}$ & siRNA & CALAA-01 & I & Solid tumors \\
\hline PKN3 & siRNA & Atu027 & I & Solid tumors \\
\hline KSP and VEGF & siRNA & ALN-VSP & I & Solid tumors \\
\hline Survivin & LNA-oligo & EZN3042 & $|/| \mid$ & Solid tumors \\
\hline HIF-1a & LNA-oligo & EZN2968 & $|/| \mid$ & Solid tumors \\
\hline Furin & shRNA & $\begin{array}{l}\text { FANG } \\
\text { vaccine }\end{array}$ & I & Solid tumors \\
\hline eiF-4E & LNA-oligo & elF-4E ASO & I & Solid tumors \\
\hline Survivin & LNA-oligo & $\begin{array}{l}\text { Survivin } \\
\text { ASO }\end{array}$ & $\|$ & Solid tumors \\
\hline
\end{tabular}

sequence elements [75] and that rasiRNAs are a subset of piRNAs.

The precise mechanism of piRNAs biogenesis is not clear, but in 2007 Brennecke et al. [73] described a new mechanism similar to secondary siRNA generation, called as ping-pong model. He observed that antisense piRNAs associate with PIWI/AUB complex while sense piRNAs associate with AGO3 protein. This information led to the suggestion that PIWI and AUB proteins bind to maternally deposited piRNAs (primary piRNA) and this complex is subsequently bound to the transcripts produced by retrotransposons and cleaves a transcript generating a sense piRNAs (secondary piRNAs) that bind to AGO3. Finally, piRNA-AGO3 complex binds to the retrotransposon transcript, creating another set of anti-sense piRNAs. However, the model of piRNAs biogenesis is still incomplete and precise mechanisms of action remain poorly characterized (for a review, see [76-78]).

The PIWI subfamily as well as piRNAs have been implicated in germ cell development, stem cell selfrenewal, and retrotransposon silencing. Recently, several studies were published describing the association between HIWI (the human ortholog of PIWI) expression and diverse group of cancers including pancreatic [79] and gastric [80] adenocarcinomas, sarcomas [81], hepatocellular carcinomas [82], colorectal cancer [83], gliomas [84] and esophageal squamous cell carcinomas [85]. It was proved that higher levels of HIWI mRNA are connected with worse clinical outcome. Moreover, the expression patern of HIWI in gastric cancer tissues was similar to that of Ki67 and suppression of HIWI induced cell cycle arrest in G2/M phase [80]. Lee et al. [86] described that PIWIL2 (PIWI-like 2) protein is widely expressed in tumors and inhibits apoptosis through activation of STAT3/BCL-X(L) signalling pathway. Similarly, the newest study of Lu et al. [87] shows that this protein forms a PIWIL2/STAT3/c-Src complex, where STAT3 is phosphorylated by c-Src and translocated to nucleus. Subsequently, STAT3 binds to P53 promoter and represses its transcription. These findings indicate that PIWI proteins may be involved in the development of different types of cancer and could be a potential target for cancer therapy. Recently, it was also proved, that not only PIWI proteins, but also piRNAs can play an important role in carcinogenesis. It was discovered that expression of piR-823 in gastric cancer tissues was significantly lower than in non-cancerous tissues. Artificial increase of the piR-823 levels in gastric cancer cells inhibited their growth. Moreover, the observations from the xenograft nude mice model confirmed its tumor suppressive properties [88]. On the contrary, levels of the piR-651 were upregulated in gastric, colon, lung, and breast cancer tissues compared to the paired 
non-cancerous tissues. The growth of gastric cancer cells was efficiently inhibited by a piR-651 inhibitor and the cells were arrested at the G2/M phase [89]. Interestingly, the peripheral blood levels of piR-651 and piR-823 in the patients with gastric cancer were significantly lower than those from controls. Thus, piRNAs may be valuable biomarkers for detecting circulating gastric cancer cells [90]. Resolving the function of PIWI proteins and piRNAs has broad implications not only in understanding their essential role in fertility, germline, stem cell development, and basic control and evolution of animal genomes, but also in the biology of cancers [12].

\section{Small nucleolar RNAs}

Small nucleolar RNAs (snoRNAs), 60 - 300 nucleotides long, represent one of the abundant groups of small ncRNAs characterized in eukaryotes. SnoRNAs are enriched in the nucleolus, which is the most prominent organelle in the interphase nucleus providing the cellular locale for the synthesis and processing of cytoplasmic ribosomal RNAs (rRNAs) [91]. Most of the snoRNAs are located within introns of protein-coding genes and are transcribed by RNA polymerase II, however, they can also be processed from introns of longer ncRNA precursors [92]. Nevertheless, while vertebrate snoRNAs are prevalently excised from pre-mRNA introns, in plant and yeast these RNAs are mainly generated from independent transcription units, as either monocistronic or (especially in plants) polycistronic snoRNA transcripts [93].

All snoRNAs fall into two major classes based on the presence of short consensus sequence motifs. First group contains the box C (RUGAUGA) and D (CUGA) motifs, whereas members of the second group are characterized by the box H (ANANNA) and ACA elements [94]. In both classes of snoRNAs, short stems bring the conserved boxes close to one another to constitute the structural core motifs of the snoRNAs, which coordinate the binding of specific proteins to form small nucleolar RNPs (snoRNPs) distinct for both groups [91,95]. SnoRNAs have important functions in the maturation of other non-coding RNAs. Above all, they manage posttranscriptional modification of rRNA and snRNA by 2'O-methylation and pseudouridylation (for a review, see [91]). Interestingly, it was identified number of human snoRNAs with miRNA-like function. These snoRNAs are processed to small 20-25 nucleotides long RNAs that stably associate with Ago proteins. Processing is independent of the Drosha, but requires Dicer. Moreover, cellular target mRNA, whose activity is regulated by snoRNA, was identified [96].

Several studies have indicated that alterations of snoRNAs play important functions in cancer development and progression. The first report linking snoRNAs to cancer was published in 2002 by Chang et al. [97]. He proved that h5sn2, a box H/ACA snoRNA, was significantly downregulated in human meningiomas compared with normal brain tissues. Subsequently, Dong et al. [98] identified snoRNA U50 as a reasonable candidate for the $6 \mathrm{q}$ tumor-suppressor gene in prostate cancer and this statement was confirmed in another study describing involvement of snoRNAs U50 in the development and/or progression of breast cancer [99]. Interestingly, chromosome $6 \mathrm{q} 14-15$ is a breakpoint of chromosomal translocation $\mathrm{t}(3 ; 6)(\mathrm{q} 27 ; \mathrm{q} 15)$ for human B-cell lymphoma [100]. The same year, the GAS5 (growth arrest-specific transcript 5) was identified to control mammalian apoptosis and cell growth. GAS5 transcript levels were found to be significantly lower in breast cancer samples relative to adjacent unaffected normal breast epithelial tissues and despite the fact that this gene has no significant protein-coding potential, it was proved that several snoRNAs are encoded in its introns [101]. By profiling ncRNAs signatures in NSCLC tissues and matched noncancerous lung tissues, four snoRNAs (snoRD33, snoRD66, snoRD76 [102] and snoRA42 [103]) were found to be overexpressed in lung tumor tissues and it is supposed that they could be used as potential markers for early detection of non-smal cell lung cancer [102]. Moreover, snoRD33 is located at chromosome 19q13.3 that contains oncogenes involved in different malignances including lung cancer, whereas snoRD66 and snoRD76 are located at chromosomal regions $3 \mathrm{q} 27.1$ and $1 \mathrm{q} 25.1$, respectively. These two chromosomal segments are the most frequently amplified in human solid tumors $[28,104,105]$. Recently, low levels of four snoRNAs (RNU44, RNU48, RNU43, RNU6B), commonly used for normalization of miRNA expression, were associated with a poor prognosis of the cancer patients [106]. Martens-Uzunova et al. [107] analyzed the composition of the entire small transcriptome by Illumina/Solexa deep sequencing and he revealed several snoRNAs with deregulated expression in samples of patients with prostate cancer. The newest publication concerning snoRNAs proved that snoRD112114 located at the DLK1-DIO3 locus are ectopically expressed in acute promyelotic leukemia (APL), which shows that a relationship exists between a chromosomal translocation and expression of snoRNA loci. Moreover, in vitro experiments revealed that the snoRD114- $[14 \mathrm{q}$ (II-1)] variant promotes cell growth through G0/G1 to $\mathrm{S}$ phase transition mediated by the $\mathrm{Rb} / \mathrm{p} 16$ pathways [108]. Finally, it was also published that snoRNAs are present in stable form in plasma and serum samples $[102,106]$ and therefore could be used as fluid-based biomarkers for cancers. These facts indicate that snoRNAs are critically associated with the development and progression of cancer, however further research for 
comprehensive understanding their role in carcinogenesis is required.

\section{Promoter-associated RNAs}

Recently, a new class of ncRNAs known as promoterassociated RNAs (paRNAs) (sometimes termed as promoter-upstream transcripts - PROMPTs [109], transcription start site-associated RNAs [110] or promoterproximal transcription start site RNAs [111]), were discovered. These ncRNAs are derived from eukaryotic promoters and have the potential to regulate the transcription of protein-coding genes by targeting epigenetic silencing complexes [71,112,113]. Their size ranged from 18 to 200 nucleotides and they include long, small and tiny RNAs.

The short paRNAs (PASRs) were identified in 2007 [114] using RNA maps. They are located near the promoter or transcription start site (TSS), but they are not associated with a known protein-coding genes. These transcripts are 20-90 nt long and it was proved that they are not Dicer product [110]. Human PASRs are expressed at low levels and their number per gene is positively correlated with promoter activity and mRNA level [109]. The tiny paRNAs or transcription iniciation RNAs (tiRNAs) are shorter than $23 \mathrm{nt}$ and they are transcribed in both sense and antisense directions around the promoter [115]. Furthermore, they are closely associated with highly expressed promoters and are preferentially located in GC-rich promoters [71,115]. It is still unclear how these two classes of small RNAs are related to one another, or if they share common biogenesis pathways [115]. Recently, a long paRNAs (PALRs, 100-200 nt) has been identified at a single-gene level and they were associated with regulatory functions (for a review, see $[112,113,116,117])$, especially with modification of DNA methylation [118].

It is supposed, that because of potential of paRNAs to regulate transcription, their deregulation could be associated with different types of diseases, including cancer. It was proved, that transfection of mimetic paRNAs into HeLa and HepG2 cells resulted in the transcriptional repression of human C-MYC and connective tissue growth factor (CTGF) [119]. Hawkins et al. [120] described that targeting of the human ubiquitin $\mathrm{C}$ gene $(U b C)$ with a small paRNA led to long-term silencing which correlated with an early increase in histone methylation and a later increase in DNA methylation at the targeted locus. Furthermore, it was shown that PASRs play an important role in maintaining accessible chromatin architecture for transcription and releasing negative supercoils during transcription [110]. Concerning tiRNAs, they may have similar functions like PASRs, moreover they are usually found at CTCF-binding sites. Taft et al. [121] proved, that overexpression of tiRNAs decreased CTCF binding and associated gene expression, whereas inhibition of
tiRNAs resulted in increased CTCF localization and associated gene expression. Wang et al. [122] described, that an RNA-binding protein TLS (for translocated in liposarcoma) can specifically bind to CREB-binding protein (CBP) and p300 histone acetyltransferase depending on its allosteric modulation by PALRs, and so repress gene target CCND1 in human cell lines. Finally, it was shown that paRNAs have the potential to form doublestranded RNAs and to be processed into endogenous siRNAs [123]. These facts indicate, that this novel class of ncRNAs has a great potential to regulate expression of various tumor suppressors and oncogenes on transcriptional level and therefore be involved in human cancerogenesis.

\section{Centromere repeat associated small interacting RNAs}

Cell stresses can induce incorrect centromere function manifesting in loss of sister chromatid cohesion, abnormal chromosome segregation, and aneuploidy, which have been observed in many human diseases including cancers [124]. These defects are often correlated with the aberrant accumulation of centromere satellite transcripts [125]. Morover, it was observed that human cells under stress accumulate large transcripts of SatIII satellites [126]. The accumulation of similar transcripts in vertebrate cells is thought to result from defective RNA processing of larger transcripts that leads to a reduction of the small RNAs that participate in the recruitment of specific histones critical for centromere function $[125,127]$. The research on mammalian model uncovered the strong bidirectional promoter capability of the kangaroo endogenous retrovirus (KERV-1) LTR to produce long double-stranded RNAs for both KERV-1 and surrounding sequences, including sat23. These long dsRNAs are then processed into centromere repeat associated small interacting RNAs (crasiRNAs), 34 - 42 nucleotides in length. Unfortunately, the mechanism by which full-length KERV-1 and sat23 transcripts are processed into crasiRNAs remains unknown. The crasiRNAs are involved in the recruitment of heterochromatin and/ or centromeric proteins. These findings have profound implications for understanding of centromere function and epigenetic identity by suggesting that a retrovirus, KERV-1, may participate in the organization of centromere chromatin structures indispensable to chromosome segregation in vertebrates [124]. These small centromereassociated ncRNAs occur conserved among eukaryotes suggesting their impact also in human.

\section{Telomere-specific small RNAs}

Another group of recently described short ncRNAs are telomere-specific small RNAs (tel-sRNAs). Tel-sRNAs are $\sim 24$ nt long, Dicer-independent, and 2'-O-methylated at the $3^{\prime}$ terminus. They are asymmetric with specificity 
toward telomere G-rich strand, and evolutionarily conserved from protozoan to mammalian cells. Interestingly, tel-sRNAs are up-regulated in cells that carry null mutation of H3K4 methyltransferase MLL and down-regulated in cells that carry null mutations of histone H3K9 methyltransferase SUV39H, suggesting that they are subject to epigenetic regulation. These results support that telsRNAs are heterochromatin associated pi-like small RNAs [128]. Recently, it was also reported that an 18-mer RNA oligo of (UUAGGG) ${ }_{3}$ has potential to inhibit telomerase TERT activity in vitro by RNA duplex formation in the template region of the telomerase RNA component [129]. Therefore, it is supposed that tel-sRNAs containing UUAGGG repeats could act as sensors of chromatin status and create a feedback loop between the telomeric heterochromatic regulation and telomere length control. Although tel-sRNAs have not been described in human until to date, they could play an important role in carcinogenesis and contribute to unlimited replicative potencial of cancer cells.

\section{Pyknons}

Pyknons are a subset of 127998 patterns of variable length, which form mosaics in untranslated as well as protein-coding regions of human genes. Nevertheless, they are found more frequently in the 3'UTR of genes than in other regions of the human genome $[130,131]$. Pyknons are present in statistically significant manner in genes that are involved in specific processes such as cell communication, transcription, regulation of transcription, signaling, transport, etc. Pyknons involve $~ 40 \%$ of the known miRNA sequences, thus suggesting possible link with posttranscriptional gene silencing and RNA interference [131]. Different sets of pyknons are connected to allele-specific sequence variations of diseaseassociated SNPs and miRNAs, suggesting that increased susceptibility to multiple common human disorders is associated with global alterations in genome-wide regulatory templates affecting the biogenesis and functions of non-coding RNAs [132].

In the time since their discovery, evidence has been slowly accumulating that these pyknon motifs mark transcribed, non-coding RNA sequences with potential functional relevance in human disease. Tsirigos et al. [133] described two GO terms (GO:0006281/DNA repair, GO:0006298/mismatch repair) that were significantly enriched in pyknons-containing regions of the human introns. He pointed out that these two terms are uniquely associated with pyknons and a search of the ENSEMBL database [134] for human genes labeled with these two GO terms identified a $M L H 1$ gene, that has been associated with hereditary non-polyposis colorectal cancer and other types of carcinomas and microsatellite instabilities. The human MLH1 transcript has 17 introns and the authors proved that these introns contain more than 10 different pyknons. Nevertheless, further research for comprehensive understanding their role in carcinogenesis is necessary.

\section{Long non-coding RNAs}

Long non-coding RNAs (lncRNAs) are the broadest class encompassed all non-protein-coding RNA species with length more than 200 nucleotides, however, frequently ranging up to $100 \mathrm{~kb}$. Many identified lncRNA are transcribed by RNA polymerase II (RNAPII), spliced, and usually contain canonical polyadenylation signals, but this is not a fast rule [2]. On the other hand, Pagano et al. [135] found out that some of these lncRNAs are due to their promoter structure likely to be transcribed by polymerase III (RNAPIII) and he marked them as cogenes since they could specifically coact with a protein-coding pol II gene. There is substantial evidence to suggest that lncRNAs mirror protein coding genes. Additionally, lncRNAs' promoters are bound and regulated by transcriptional factors and epigenetically marked with specific histone modifications [136]. LncRNAs are developmentally and tissue specific, and have been associated with a spectrum of biological processes, for example, alternative splicing, modulation of protein activity, alternation of protein localization, and epigenetic regulation. LncRNAs can be also precursors of small RNAs and even tools for miRNAs silencing [71,137-141]. However, one of their primary tasks appears to be regulators of protein-coding gene expression (Figure 3) [142]. Recently, Wang et al. [143] described four different mechanisms of IncRNAs action. He supposes that these molecules can function as signals, decoys, guides or as scaffolds (Figure 4). It is not surprising, then, that dysregulation of lncRNAs seems to be an important feature of many complex human diseases, including cancer (Table 4), ischaemic heart disease [144] and Alzheimer's disease [145]. Also dysregulation of lncRNAs that function as regulators of the expression of tumor suppressors or oncogenes, and not the protein-coding sequence itself, may be one of the 'hits' that leads to oncogenesis [2]. That is why they might be suitable as potential biomarkers and targets for novel therapeutic approaches in the future.

\section{Long intergenic non-coding RNAs}

Long intergenic non-coding RNAs (lincRNAs) are newly discovered ncRNAs belonging to lncRNAs. RNAs of this subclass ranging in length from several hundred to tens of thousands of bases and they lie within the genomic intervals between two genes. More than 3000 human lincRNAs have been identified, but less than $1 \%$ has been characterized $[136,186]$. It was shown that distinct lincRNAs are involved in diverse biological processes 


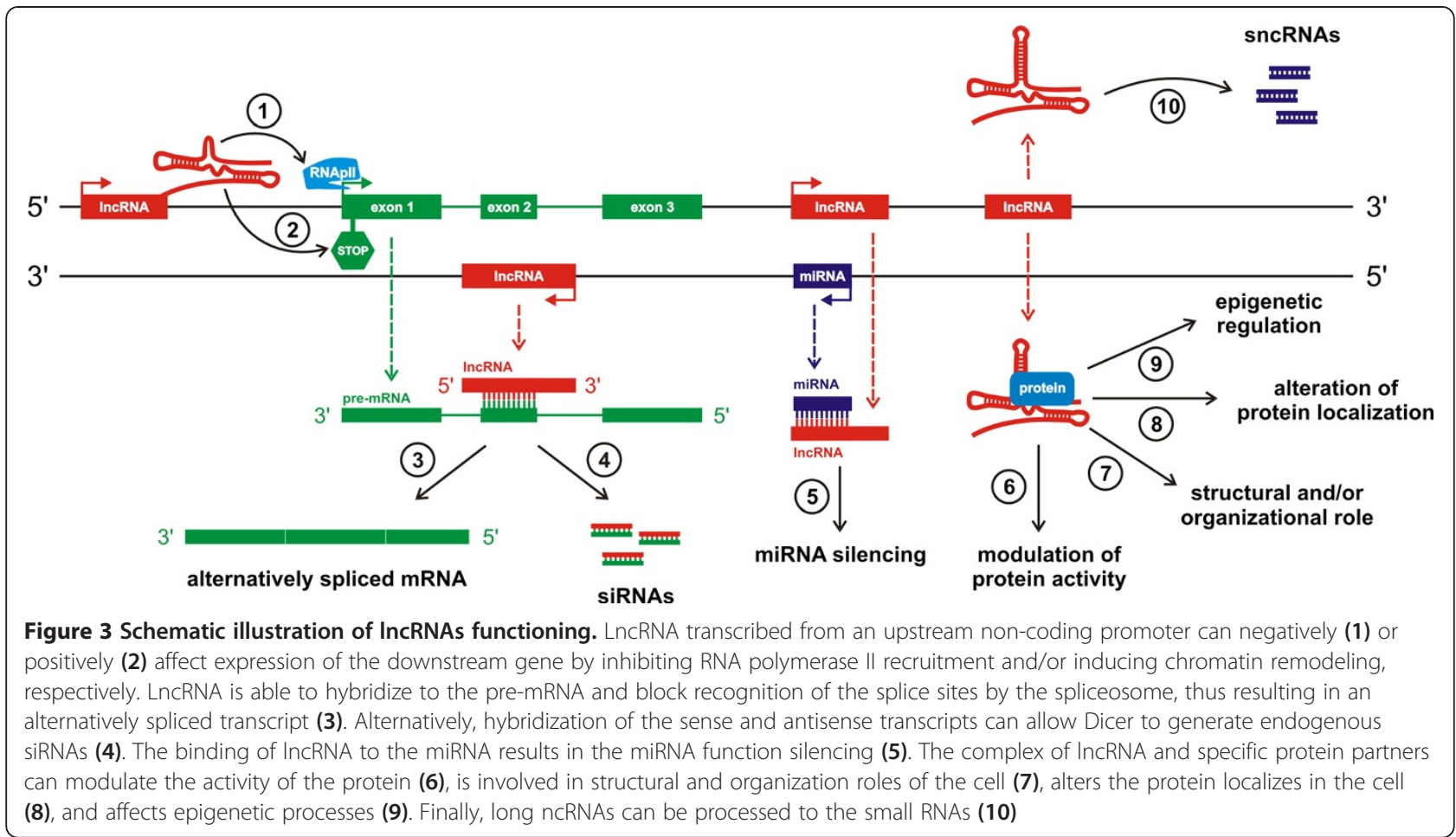

such as imprinting or cancer metastasis $[7,140,186]$. Moreover, recent studies proved that lincRNAs are exquisitely regulated during development and in response to diverse signaling cues, and exhibit distinct gene expression patterns in primary tumors and metastases [136]. Therefore, these IncRNAs could be utilized for cancer diagnosis, prognosis, and serve as potential therapeutic targets.

Recently it has been demonstrated that lncRNAs can act as natural 'miRNA sponges' to reduce miRNA levels [155]. The most highly upregulated transcript found in a microarray-based study of gene expression in hepatocellular carcinoma was determined to be the ncRNA HULC, or Highly Upregulated in Liver Cancer. Transcribed from chromosome 6p24.3, this lncRNA demonstrates the hallmarks of a typical mRNA molecule, including a single spliced GT-AG intron, canonical polyadenylation signals upstream of the poly(A) tail and nuclear export demonstrating strong localization to the cytoplasm. Although HULC was found to co-purify with ribosomes, no translation product for this lncRNA has been detected, supporting its classification as a noncoding transcript [156]. In addition to liver cancer, HULC was found to be highly upregulated in hepatic colorectal cancer metastasis and in hepatocellular carcinoma cell lines (HCC) producing hepatitis B virus (HBV) [157]. HULC exists as part of an intricate autoregulatory network, which when perturbed, resulted in increased HULC expression (Figure 5a). The HULC
RNA appeared to function as a 'molecular decoy' or 'miRNA sponge' sequestering miR-372, of which one function is the translational repression of PRKACB, a kinase targeting cAMP response element binding protein (CREB). Once activated, the CREB protein was able to promote HULC transcription by maintaining an open chromatin structure at the HULC promoter resulting in increased HULC transcription [158].

Another well known RNA that belongs to lncRNA subclass described in previous paragraph is HOX antisense intergenic RNA (HOTAIR) (see Figure 5b). HOTAIR is $2.2 \mathrm{~kb}$ gene localized within the human HOXC gene cluster on the long arm of chromosome 2 . It has been shown that this lincRNA has a potential to regulate HOXD genes in trans via the recruitment of polycomb repressive complex 2 (PRC2), followed by the trimethylation of lysine 27 of histone $\mathrm{H} 3$ [7]. In general, the $5^{\prime}$ region of the RNA binds the PRC2 complex responsible for H3K27 methylation, while the 3' region of HOTAIR binds LSD1 (flavin-dependent monoamine oxidase), a histone lysine demethylase that mediates enzymatic demethylation of H3K4Me2. HOTAIR exists in mammals, has poorly conserved sequences and considerably conserved structures, and has evolved faster than nearby HOXC genes [187]. HOTAIR was one of the first metastasis-associated lncRNAs, described to have a fundamental role in cancer. This lncRNA was found to be highly upregulated in both primary and metastatic breast tumors, showing up to 2000-fold increased transcription 


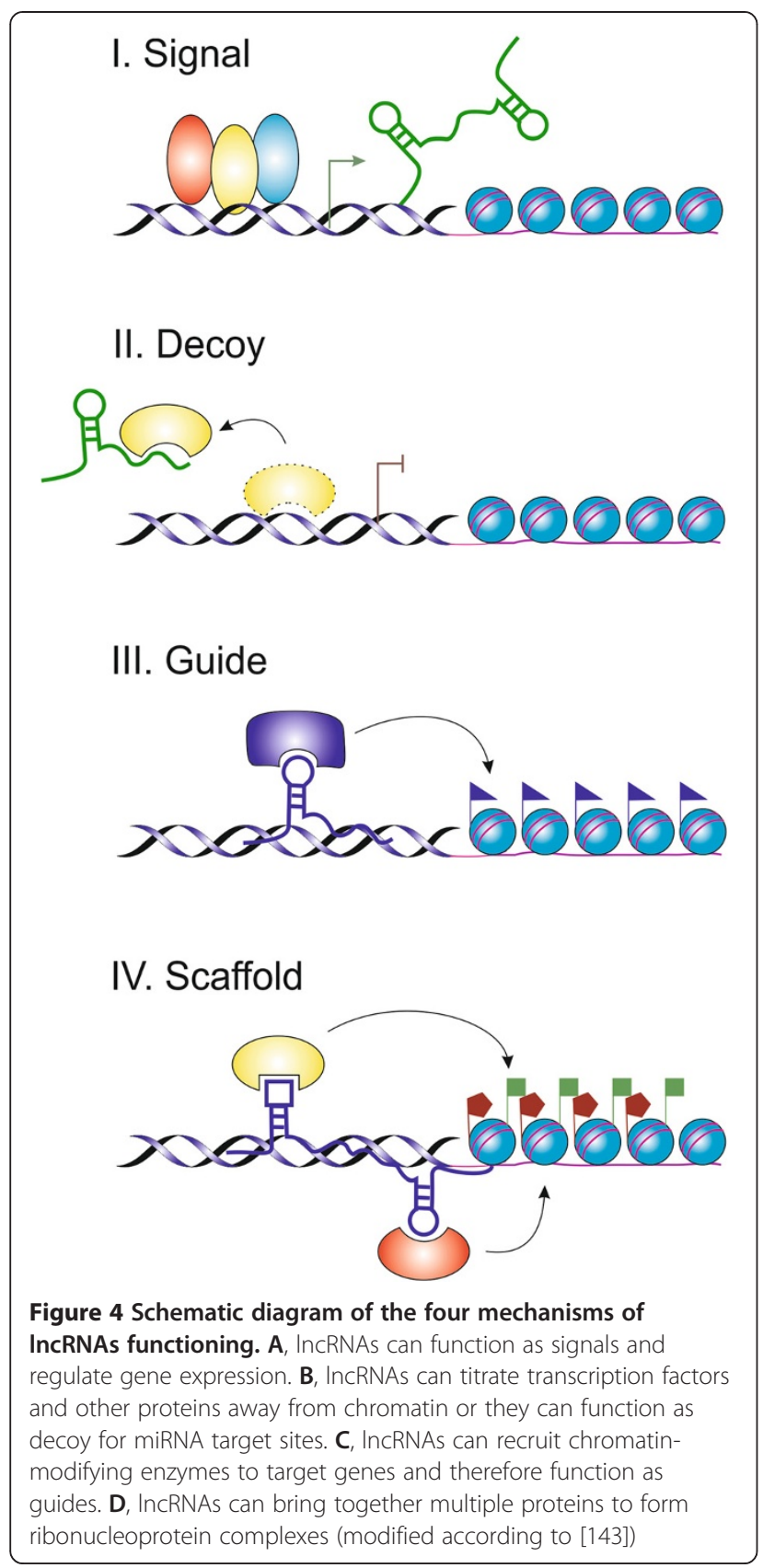

over normal breast tissue. This phenotype seems to be closely linked with PRC2-dependent gene repression induced by HOTAIR. High levels of HOTAIR expression correlate with both metastasis and poor survival rate, connecting lncRNAs with tumor invasiveness and patient prognosis [140]. In addition, it was observed that the high expression level of HOTAIR in hepatocellular carcinoma could be a candidate biomarker for predicting tumor recurrence in hepatocellular carcinoma patients who have undergone liver transplant therapy and might be a potential therapeutic target [188]. Huarte et al. [189] identified several lincRNAs that are regulated by p53. Furthermore, he proved that lincRNAs-p21 serves as a repressor in p53-dependent transcriptional responses, since inhibition of this lincRNA affected the expression of hundreds of gene targets enriched for genes normally repressed by $\mathrm{p} 53$.

While targeting cancer-specific miRNAs has proven to be successful, it will be necessary to design molecules with potential to inhibit lincRNAs. Gupta et al. [140] proved that these molecules can be depleted by siRNAs, but this possibility is quite complicated because of extensive secondary structures in lincRNAs [187]. Nevertheless, it is evident that cancer-associated lincRNAs may provide new approaches to the diagnosis and treatment of cancer.

\section{Long intronic non-coding RNAs}

The biogenesis of long intronic ncRNAs is poorly understood at this time. Nevertheless, there are some indirect evidences that indicate an involvement of RNA polymerase II (RNAPII). Among such evidences belong a concordant and co-regulated expression profiles of many intronic ncRNAs and their corresponding proteincoding genes, the broad contribution of RNAPII associated transcription factors and physiological stimuli in the transcription of intronic ncRNAs as well the presence of poly(A+) tail [190-194]. Nonetheless, it is described that over $10 \%$ of long intronic poly $(\mathrm{A}+)$ ncRNAs are up-regulatated compared to only $4 \%$ of protein-coding transcripts after treatment with the RNAPII specific inhibitor $\alpha$-amanitin $[190,193,195]$. These findings suggest that some intronic ncRNA and peculiar protein-coding RNAs could be transcribed by another RNA polymerase such as the recently described spRNAP-IV, whose transcriptional output seems to be enhanced by $\alpha$-amanitin, or also could be transcribed by RNAP III [190,195-199].

Similarly to lincRNAs, there are also described evolutionary conserved long intronic ncRNAs sequences from mouse and human [200,201]. When the introns of a larger selection of vertebrates were aligned, the length of the conserved region became only $100 \mathrm{bp}$, while in the alignment of a smaller group of closely related species (human-mouse-cow-dog) the evolutionary conservation of the region extended to as much as $750 \mathrm{bp}$ [201].

The widespread occurrence, tissue and subcellular expression specificity, evolutionary conservation, environment alteration responsiveness and aberrant expression in human cancers are features that accredit intronic ncRNAs to be mediators of gene expression regulation. A few sets of intronic ncRNAs have the same tissue expression pattern as the corresponding protein-coding genes, whereas others are inversely correlated. These findings point to complex regulatory relationships between intronic ncRNAs and their host loci $[190,193,202,203]$. Some small ncRNAs are encoded within intronic regions; moreover, intronic 
Table 4 Human cancer associated IncRNAs (adapted from [4])

\begin{tabular}{|c|c|c|c|c|}
\hline LncRNA & Size & Cytoband & Cancer types & References \\
\hline HOTAIR & $2158 \mathrm{nt}$ & $12 q 13.13$ & breast & {$[7,140]$} \\
\hline MALAT1/a/NEAT2 & $7.5 \mathrm{~kb}$ & $11 q 13.1$ & $\begin{array}{l}\text { breast, lung, uterus, pancreas, colon, prostate, } \\
\text { liver, osteosarcoma, neuroblastoma, cervix }\end{array}$ & {$[146-151]$} \\
\hline HULC & $500 \mathrm{nt}$ & $6 \mathrm{p} 24.3$ & liver & {$[152,153]$} \\
\hline BC200 & $200 \mathrm{nt}$ & $2 p 21$ & breast, cervix, esophagus, lung, ovary, parotid, tongue & {$[154,155]$} \\
\hline $\mathrm{H} 19$ & $2.3 \mathrm{~kb}$ & $11 \mathrm{p} 15.5$ & $\begin{array}{l}\text { bladder, lung, liver, breast, endometrial, cervix esophagus, } \\
\text { ovary, prostate, colorectal }\end{array}$ & [156-159] \\
\hline BIC/MIRHG155/MIRHG2 & $1.6 \mathrm{~kb}$ & $21 q 11.2$ & B-cell lymphoma & {$[160]$} \\
\hline PRNCR1 & $13 \mathrm{~kb}$ & $8 q 24.2$ & prostate & [161] \\
\hline LOC285194 & $2105 \mathrm{nt}$ & $3 q 13.31$ & osteosarcoma & {$[162]$} \\
\hline PCGEM1 & $1643 \mathrm{nt}$ & $2 \mathrm{~g} 32.2$ & prostate & [163-165] \\
\hline UCA1/CUDR & $1.4-2.7 \mathrm{~kb}$ & $19 p 13.12$ & $\begin{array}{l}\text { bladder, colon, cervix, lung, thyroid, liver, } \\
\text { breast, esophagus, stomach }\end{array}$ & {$[166]$} \\
\hline DD3/PCA3 & $0.6-4 \mathrm{~kb}$ & $9 q 21.22$ & prostate & {$[167,168]$} \\
\hline anti-NOS2A & $1.9 \mathrm{~kb}$ & $17 q 23.2$ & brain & [169] \\
\hline uc.73A & $201 \mathrm{nt}$ & $2 q 22.3$ & colon & {$[170]$} \\
\hline uc.338 & $590 \mathrm{nt}$ & $12 q 13.13$ & liver & {$[171]$} \\
\hline ANRIL/p15AS/CDK2BAS & $34.8 \mathrm{~kb}$ & $9 p 21.3$ & prostate, leukemia & [172-175] \\
\hline MEG3 & $1.6 \mathrm{~kb}$ & $14 q 32.2$ & brain & [176-178] \\
\hline GAS5/SNHG2 & isoforms & $1 q 25.1$ & breast & {$[101]$} \\
\hline SRA-1/SRA & $1965 \mathrm{nt}$ & $5 q 31.3$ & breast, uterus, ovary & {$[179,180]$} \\
\hline PTENP1 & $3.9 \mathrm{~kb}$ & $9 p 13.3$ & prostate & {$[181,182]$} \\
\hline ncRAN & 2186 nt 2087 nt & $17 q 25.1$ & bladder, neuroblastoma & {$[183,184]$} \\
\hline LSINCT5 & $2.6 \mathrm{~kb}$ & $5 p 15.33$ & breast, ovary & [185] \\
\hline
\end{tabular}

miRNAs tend to be present in large introns with $5^{\prime}$-biased position distribution, what correlates with the previous observation that most long intronic transcripts are expressed within first introns of the host genes. Thus, it is expected that a number of long intronic ncRNAs are processed into smaller ncRNAs [68,190,204,205]. Similar to lincRNAs HOTAIR, Heo et al. [206] described a long intronic noncoding RNA termed as cold assisted intronic non-coding RNA - COLDAIR, which is required for the vernalizationmediated epigenetic repression of FLC mediated by PRC2. Interestingly, the newest study of Tahira et al. [207] shows that long intronic non-coding RNAs are differentially expressed in primary and metastatic pancreatic cancer. Moreover, loci harbouring intronic lncRNAs differentially expressed in pancreatic ductal carcinoma metastases were enriched in genes associated to the MAPK pathway. These findings indicate potential relevance of this class of transcripts in biological processes related to malignant transformation and metastasis.

\section{Telomere-associated ncRNAs}

Telomeres protect linear chromosome ends from being recognized and processed as double-strand breaks by
DNA repair activities. This protective function of telomeres is essential for chromosome stability. Until recently, the heavily methylated state of subtelomeric regions, the gene-less nature of telomeres, and the observed telomere position effect led to the notion that telomeres are transcriptionally silent [208]. This hypothesis was recently challenged when several groups independently demonstrated that subtelomeric and telomeric regions, although devoid of genes, have the potential to be transcribed into telomeric UUAGGG-repeat containing ncRNAs (TERRA) [209-211]. TERRA molecules are conserved among eukaryotes and have been identified also in human. TERRA transcripts are synthesized from the C-rich strand and polyadenylated, and their synthesis is $\alpha$-amanitin-sensitive, suggesting that they are transcripts of RNAPII [208,212]. TERRA molecules range between $100 \mathrm{bp}$ and $>9 \mathrm{~kb}$ in length and were reported to form intermolecular G-quadruplex structure with single-stranded telomeric DNA, but can also fold into a compact repeated structure containing G-quartets [211]. TERRA transcripts can be found throughout the different stages of the cell cycle, and their levels are affected by several factors that include telomere length, tumor 

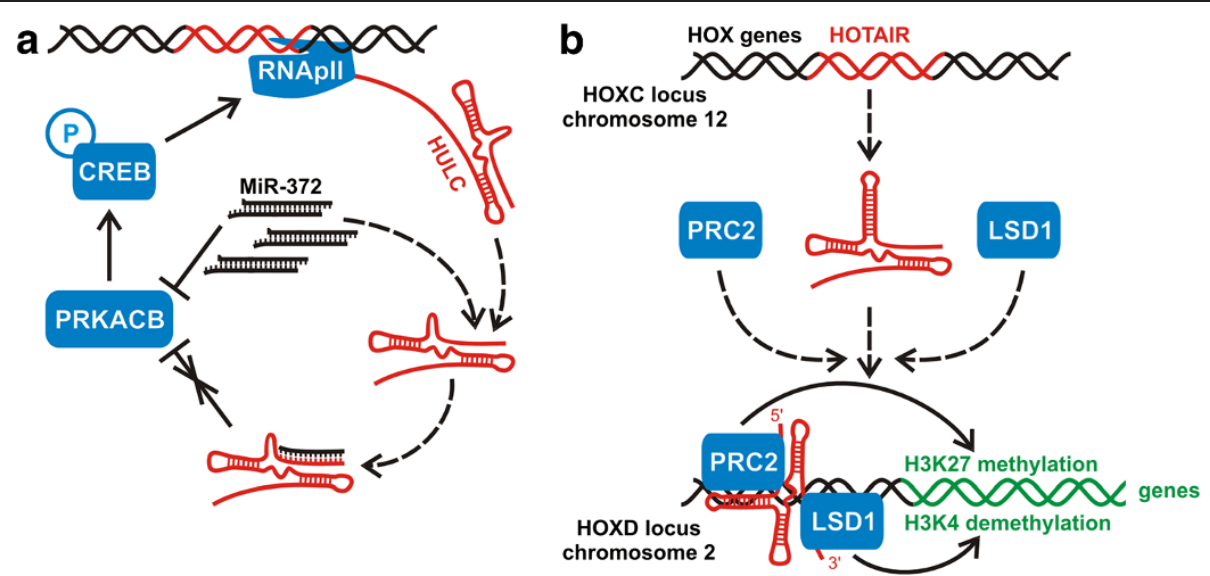

Figure 5 Proposed mechanism of HULC up-regulation in hepatocellular carcinoma (a) and HOTAIR mediated gene silencing of $40 \mathrm{~kb}$ of the HOXD locus (b).

stage, cellular stress, developmental stage, and telomeric chromatin structure [208].

TERRA most likely negatively regulates telomere length [211]. Increased TERRA levels by interfering with TERRA decay, such as the impairment of non-sense-mediated RNA decay in human cells or by deletion of the $5^{\prime}-3^{\prime}$ exonuclease Rat1p in Saccharomyces cerevisiae, are associated with a loss of telomere reserve [209,212]. Current models propose a role for TERRA in controlling telomerase activity. In yeast, the formation of a DNA/RNA hybrid between TERRA and telomeres is thought to inhibit elongation by telomerase, whereas in mammals, TERRA was shown to efficiently inhibit telomerase activity in vitro, presumably by base pairing with the template region of the RNA component of telomerase [208,210,212]. Caslini et al. [213] described that telomere uncapping through either TRF2 shelterin protein knockdown or exposure to telomere Gstrand DNA oligonucleotides significantly increases the transcription of TERRA, an effect mediated by the functional cooperation between transcriptional regulator MLL and the tumor suppressor p53. Sampl et al. [214] found out that the expression of TERRA in patients with glioblastoma multiforme negatively correlates with the grade. Moreover, this finding of a diagnostic value of TERRA levels in astrocytoma WHO grade 2 to 4 corresponded with preliminary data in advances stages of human tumors of larynx, colon, and lymph node [210]. Unfortunately, it is largely unclear how the expression of TERRA and the amount of TERRA transcripts are regulated in the cell [208]. Nevertheless, TERRA opens new avenues for telomere research that will impact on telomere-associated diseases including many cancers [215].

\section{Long ncRNAs with dual functions}

Until not long ago, ncRNAs were strictly considered as RNA molecules with regulatory functions but not associated with the protein coding capacity typical of messenger RNAs. However, the recent identification and characterization of bifunctional RNAs, i.e. RNAs for which coding capacity and activity as functional regulatory RNAs have been reported, suggests that a definite categorization of some RNA molecules is far from being straightforward [216]. The steroid receptor RNA activator (SRA) is a unique co-regulator that functions as a non-coding RNA, although incorporation of an additional 5 ' region can result in translation of an SRA protein (SRAP) that also has co-activator activity $[180,217,218]$. SRA was initially shown to enhance gene expression through a ribonucleoprotein complex with steroid receptors and SRC-1 [217]. Currently, SRA is known as an RNA co-activator for many other nuclear receptors. In addition, SRA may act as an RNA scaffold for corepressor complexes [216,219]. SRA transcripts have been identified in normal human tissues, with a higher expression in liver, skeletal muscle, adrenal and pituitary glands, whereas intermediate expression levels were observed in the placenta, lung, kidney and pancreas [217]. In some pathological cases, increased RNA levels of SRA were reported like in breast and ovarian tumors [179,220,221]. Interestingly, levels of SRA expression could be characteristic of tumor grade or particular subtypes of lesions among different tumors. Indeed, serous ovarian tumors showed higher levels of SRA than granulosa tumor cells $[216,220]$.

\section{Pseudogene RNAs}

Pseudogenes are gene copies that have lost the ability to code for a protein; they are typically identified through annotation of disabled, decayed or incomplete protein-coding sequences. These molecules have long been labeled as "junk" DNA, failed copies of genes that arise during the evolution of genomes. However, 
recent results showed that some pseudogenes appear to harbor the potential to regulate their protein-coding cousins [222,223]. Processed pseudogenes are made through retrotransposition of mRNAs, especially as a possible byproduct of LINE-1 (Long INterspersed Elements) retrotransposition. Thus, these mRNAs are reverse transcribed and re-integrated into the genomic DNA $[224,225]$. The parent gene of the mRNA need not to be on the same chromosome as the retrotransposed copy. Retrotransposed mRNAs have three possible fates in the genome: formation of processed genes, formation of non-transcribed pseudogenes, or formation of pseudogenes transcribed into RNAs [222]. Interestingly, some of these RNAs exhibit a tissue-specific pattern of activation. Pseudogene transcripts can be processed into short interfering RNAs that regulate coding genes through the RNAi pathway. In another remarkable discovery, it has been shown that pseudogene RNAs are capable of regulating tumor suppressors and oncogenes by acting as microRNA decoys [223,225]. Moreover, Devor et al. [226] found out that primate-specific miRNAs, miR-220 and miR-492, each lie within a processed pseudogene. Several studies also show deregulated expression of these molecules during cancer progression, which provides evidence for the functional involvement of pseudogene RNAs in carcinogenesis and suggests these molecules as a potential novel diagnostic or therapeutic target in human cancers. One of these pseudogenes is myosin light chain kinase pseudogene (MYLK). MYLKP1 is partially duplicated from the original MYLK gene that encodes nonmuscle and smooth muscle myosin light chain kinase (smMLCK) isoforms and regulates cell contractility and cytokinesis. Despite strong homology with the smMLCK promoter ( 90\%), the MYLKP1 promoter is minimally active in normal bronchial epithelial cells, but highly active in lung adenocarcinoma cells. Moreover, MYLKP1 and smMLCK exhibit negatively correlated transcriptional patterns in normal and cancer cells with MYLKP1 strongly expressed in cancer cells and smMLCK highly expressed in non-neoplastic cells. For instance, expression of smMLCK decreased in colon carcinoma tissues compared to normal colon tissues. Mechanistically, MYLKP1 overexpression inhibits smMLCK expression in cancer cells by decreasing RNA stability, leading to increased cell proliferation. These findings provide strong evidence for the functional involvement of pseudogenes in carcinogenesis and suggest MYLKP1 as a potential novel diagnostic or therapeutic target in human cancers [227]. Using massively parallel signature sequencing (MPSS) technology, RT-PCR, and 5' rapid amplification of cDNA ends (RACE) a novel androgen regulated and transcribed pseudogene of kallikreins termed as KLK31P was discovered. It was further proved that this pseudogene may play an important role in prostate carcinogenesis [228]. He et al. [229] found out that pseudogene RNAs are also able to regulate a dosage of PTEN tumor suppressor during tumor development. Pseudogene RNAs however, warrant further investigation into the true extent of their function $[223,227]$.

\section{Transcribed-ultraconserved regions}

Ultraconcerved regions (UCRs) are a subset of conserved sequences that are located in both intra- and intergenic regions. They are 481 sequences, longer than $200 \mathrm{bp}$ that are absolutely conserved between orthologous regions of human, rat, and mouse genomes [230]. Calin et al. [170] have proved in cancer systems that differentially expressed UCR could alter the functional characteristics of malignant cells. The link between genomic location of UCRs and analyzed cancer-related genomic elements is highly statistically significant and comparable to that reported for miRNAs. UCRs are frequently located at fragile sites and genomic regions involved in cancers. Using northern blot, qRT-PCR and microarray analysis, it was revealed that UCRs have distinct signatures in human leukemias and carcinomas [170].

Majority of UCRs are transcribed (T-UCRs) in normal human tissues, both ubiquitously and tissue specifically. From the molecular point of view, untranscribed UCRs might have regulatory functions as enhancers [231], while many functions can be assigned for T-UCRs, such as antisense inhibitors for protein-coding genes or other ncRNAs, including miRNAs. On the other hand, instead of T-UCRs interacting with protein-coding genes and miRNAs, it is possible that miRNAs control T-UCRs. Evidence supporting this predication is that many TUCRs have significant antisense complementarity with particular miRNAs and negative correlation between expression of specific T-UCRs and predicted interactor miRNAs $[170,232]$.

The expression of many T-UCRs is significantly altered in cancer, especially in adult chronic lymphocytic leukemias, colorectal and hepatocellular carcinomas and neuroblastomas [170]. Their aberrant transcription profiles can be used to distinguish types of human cancers and have been linked to patient outcome [233]. Especially in neuroblastoma, functional T-UCR annotations, inferred through a functional genomics approach and validated using cellular models, reveal associations with several cancer-related cellular processes such as apoptosis and differentiation [234]. Further, DNA hypomethylation induces release of T-UCR silencing in cancer cells. Studies of primary human tumors have shown that hypermethylation of T-UCR CpG islands is common event 
among the various tumor types. Thus in addition to miRNAs, another class of ncRNAs (T-UCRs) undergoes DNA methylation-associated inactivation in transformed cells, and so supports model that both epigenetic and genetic alterations in coding and noncoding sequences cooperate in human tumorigenesis. Most importantly, restoration of T-UCR expression was observed upon treatment with the DNA-demethylating agent [232]. Another study proved, that SNPs (single nucleotide polymorphisms) rs9572903 and rs2056116 in ultraconserved regions were associated with increased familial breast cancer risk [235]. Because of increasing number of studies concerning T-UCRs is published, it is supposed that the more specific roles of these molecules in cancer will be known in a short time.

\section{Conclusions and future perspectives}

For a long time, the central dogma of molecular biology proposed RNA molecules primarily to be informational "messenger" between DNA and protein. But, surprisingly, only $2 \%$ of the human genome sequence encodes proteins, while a large part of it is devoted to the expression of ncRNAs, which are divided into two main groups according to their nucleotide length - small and long ncRNAs. These molecules are suggested to be important regulators of gene expression. Nevertheless, the two groups of ncRNAs are distinct in their biological functions and mechanisms of gene regulations. Small ncRNAs are involved mainly in the post-transcriptional gene regulation using translational repression or RNAi pathway, while long ncRNAs are much more involved in epigenetic regulation. In many cases, differential expression of ncRNAs is becoming recognized as a one of the hallmarks of cancer cell, indicating their potential usage as the novel diagnostic, prognostic, or predictive biomarkers. Growing evidence also suggests that ncRNAs have the promising potential in targeted regulation of gene expression and, therefore, in cancer targeted therapy. However, the function of many ncRNAs remains unknown and it will be necessary to discover the precise mechanisms by which are these molecules involved in carcinogenesis.

\section{Competing interest}

The authors declare that they have no competing interests.

\section{Acknowledgements}

This work was supported by grant IGA 10361-3/2009, NS/9814-4/2008, NS 10352-3/2009, NS/11214-4/2010 of the Czech Ministry of Health, Project No. MZOMOU2005 of the Czech Ministry of Health and by the project "CEITEC Central European Institute of Technology" (CZ.1.05/1.1.00/02.0068).

\footnotetext{
Author details

${ }^{1}$ Masaryk Memorial Cancer Institute, Department of Comprehensive Cancer Care, Zluty kopec 7, Brno, Czech Republic, Europe. ${ }^{2}$ Central European Institute of Technology, Masaryk University, Brno, Czech Republic, Europe. ${ }^{3}$ Masaryk Memorial Cancer Institute, Department of Comprehensive Cancer Care, Zluty kopec 7, 656 53, Brno, Czech Republic, Europe.
}

\section{Authors' contributions}

SJ and FP drafted the manuscript, SM and SO revised the manuscript critically for important and intellectual content. All authors read and approved the final manuscript. All authors read and approved the final manuscript.

Received: 2 January 2012 Accepted: 21 May 2012

Published: 21 May 2012

\section{References}

1. Stein LD: Human genome: end of the beginning. Nature 2004, 431:915-916.

2. Taft RJ, Pang KC, Mercer TR, Dinger M, Mattick JS: Non-coding RNAs: regulators of disease. J Pathol 2010, 220:126-139.

3. Knowling S, Morris KV: Non-coding RNA and antisense RNA. Nature's trash or treasure? Biochimie 2011, 93:1922-1927.

4. Mattick JS: Non-coding RNAs: the architects of eukaryotic complexity. EMBO Rep 2001, 2:986-991.

5. Costa FF: Non-coding RNAs: new players in eukaryotic biology. Gene 2005, 357:83-94

6. Okamura K, Chung W-J, Ruby JG, Guo H, Bartel DP, Lai EC: The Drosophila hairpin RNA pathway generates endogenous short interfering RNAs. Nature 2008, 453:803-806.

7. Rinn JL, Kertesz M, Wang JK, Squazzo SL, Xu X, Brugmann SA, Goodnough LH, Helms JA, Farnham PJ, Segal E, Chang HY: Functional demarcation of active and silent chromatin domains in human HOX loci by noncoding RNAs. Cell 2007, 129:1311-1323.

8. Elbashir SM, Harborth J, Lendeckel W, Yalcin A, Weber K, Tuschl T: Duplexes of 21-nucleotide RNAs mediate RNA interference in cultured mammalian cells. Nature 2001, 411:494-498.

9. Meister $\mathrm{G}$, Tuschl T: Mechanisms of gene silencing by double-stranded RNA. Nature 2004, 431:343-349.

10. Lippman Z, Martienssen R: The role of RNA interference in heterochromatic silencing. Nature 2004, 431:364-370.

11. Houwing S, Kamminga LM, Berezikov E, Cronembold D, Girard A, van den Elst H, Filippov DV, Blaser H, Raz E, Moens CB, Plasterk RHA, Hannon GJ, Draper BW, Ketting RF: A role for Piwi and piRNAs in germ cell maintenance and transposon silencing in Zebrafish. Cell 2007, 129:69-82.

12. Seto AG, Kingston RE, Lau NC: The coming of age for Piwi proteins. Mol Cell 2007, 26:603-609.

13. Sana J, Hajduch M, Michalek J, Vyzula R, Slaby O: MicroRNAs and glioblastoma: roles in core signalling pathways and potential clinical implications. J Cell Mol Med 2011, 15:1636-1644.

14. Slaby O, Bienertova-Vasku J, Svoboda M, Vyzula R: Genetic polymorphisms and microRNAs: new direction in molecular epidemiology of solid cancer. J Cell Mol Med 2012, 16:8-21.

15. Slaby O, Svoboda M, Michalek J, Vyzula R: MicroRNAs in colorectal cancer: translation of molecular biology into clinical application. Mol Cancer 2009, 8:102

16. Redova M, Svoboda M, Slaby O: MicroRNAs and their target gene networks in renal cell carcinoma. Biochem Biophys Res Commun 2011 405:153-156.

17. Lee RC, Feinbaum RL, Ambros V: The C. elegans heterochronic gene lin- 4 encodes small RNAs with antisense complementarity to lin-14. Cell 1993, 75:843-854.

18. Griffiths-Jones S: miRBase: the microRNA sequence database. Methods Mol Biol 2006, 342:129-138.

19. Krol J, Loedige I, Filipowicz W: The widespread regulation of microRNA biogenesis, function and decay. Nat Rev Genet 2010, 11:597-610.

20. Roberts APE, Lewis AP, Jopling CL: miR-122 activates hepatitis C virus translation by a specialized mechanism requiring particular RNA components. Nucleic Acids Res 2011, 39:7716-7729.

21. Grey F, Tirabassi R, Meyers H, Wu G, McWeeney S, Hook L, Nelson JA: A viral microRNA down-regulates multiple cell cycle genes through mRNA $5^{\prime}$ UTRs. PLoS Pathog 2010, 6:e1000967.

22. Tsai N-P, Lin Y-L, Wei L-N: MicroRNA mir-346 targets the 5'-untranslated region of receptor-interacting protein 140 (RIP140) mRNA and upregulates its protein expression. Biochem J 2009, 424:411-418.

23. Ørom UA, Nielsen FC, Lund AH: MicroRNA-10a binds the 5'UTR of ribosomal protein mRNAs and enhances their translation. Mol Cell 2008, 30:460-471 
24. Farh KK-H, Grimson A, Jan C, Lewis BP, Johnston WK, Lim LP, Burge CB, Bartel DP: The widespread impact of mammalian MicroRNAs on mRNA repression and evolution. Science 2005, 310:1817-1821.

25. Lim LP, Lau NC, Garrett-Engele P, Grimson A, Schelter JM, Castle J, Bartel DP Linsley PS, Johnson JM: Microarray analysis shows that some microRNAs downregulate large numbers of target mRNAs. Nature 2005, 433:769-773.

26. Lee I, Ajay SS, Yook Jl, Kim HS, Hong SH, Kim NH, Dhanasekaran SM, Chinnaiyan AM, Athey BD: New class of microRNA targets containing simultaneous 5'-UTR and 3'-UTR interaction sites. Genome Res 2009, 19:1175-1183.

27. Chi SW, Zang JB, Mele A, Darnell RB: Argonaute HITS-CLIP decodes microRNA-mRNA interaction maps. Nature 2009, 460:479-486.

28. Li M, Li J, Ding X, He M, Cheng S-Y: microRNA and cancer. AAPS J 2010, 12:309-317.

29. Kwak PB, Iwasaki S, Tomari Y: The microRNA pathway and cancer. Cancer Sci 2010, 101:2309-2315.

30. Wu WKK, Law PTY, Lee CW, Cho CH, Fan D, Wu K, Yu J, Sung JJY: MicroRNA in colorectal cancer: from benchtop to bedside. Carcinogenesis 2011, 32:247-253.

31. Lin P-Y, Yu S-L, Yang P-C: MicroRNA in lung cancer. Br J Cancer 2010, 103:1144-1148.

32. Lakomy R, Sana J, Hankeova S, Fadrus P, Kren L, Lzicarova E, Svoboda M, Dolezelova H, Smrcka M, Vyzula R, Michalek J, Hajduch M, Slaby O: MiR-195, miR-196b, miR-181c, miR-21 expression levels and 0-6-methylguanine -DNA methyltransferase methylation status are associated with clinical outcome in glioblastoma patients. Cancer Sci 2011, 102:2186-2190.

33. Satoh J: MicroRNAs and their therapeutic potential for human diseases: aberrant microRNA expression in Alzheimer's disease brains. J Pharmacol Sci 2010, 114:269-275.

34. Slaby O, Jancovicova J, Lakomy R, Svoboda M, Poprach A, Fabian P, Kren L, Michalek J, Vyzula R: Expression of miRNA-106b in conventional renal cell carcinoma is a potential marker for prediction of early metastasis after nephrectomy. J Exp Clin Cancer Res 2010, 29:90.

35. Slaby O, Lakomy R, Fadrus P, Hrstka R, Kren L, Lzicarova E, Smrcka M, Svoboda M, Dolezalova H, Novakova J, Valik D, Vyzula R, Michalek J: MicroRNA-181 family predicts response to concomitant chemoradiotherapy with temozolomide in glioblastoma patients. Neoplasma 2010, 57:264-269.

36. Bloomston M, Frankel WL, Petrocca F, Volinia S, Alder H, Hagan JP, Liu C-G, Bhatt D, Taccioli C, Croce CM: MicroRNA expression patterns to differentiate pancreatic adenocarcinoma from normal pancreas and chronic pancreatitis. JAMA 2007, 297:1901-1908.

37. Fornari F, Gramantieri L, Giovannini C, Veronese A, Ferracin M, Sabbioni S, Calin GA, Grazi GL, Croce CM, Tavolari S, Chieco P, Negrini M, Bolondi L: MiR-122/cyclin G1 interaction modulates p53 activity and affects doxorubicin sensitivity of human hepatocarcinoma cells. Cancer Res 2009, 69:5761-5767.

38. Gramantieri L, Fornari F, Ferracin M, Veronese A, Sabbioni S, Calin GA, Grazi GL, Croce CM, Bolondi L, Negrini M: MicroRNA-221 targets Bmf in hepatocellular carcinoma and correlates with tumor multifocality. Clin Cancer Res 2009, 15:5073-5081.

39. Slaby O, Svoboda M, Fabian P, Smerdova T, Knoflickova D, Bednarikova M, Nenutil R, Vyzula R: Altered expression of miR-21, miR-31, miR-143 and miR-145 is related to clinicopathologic features of colorectal cancer. Oncology 2007, 72:397-402.

40. Kulda V, Pesta M, Topolcan O, Liska V, Treska V, Sutnar A, Rupert K, Ludvikova M, Babuska V, Holubec L Jr, Cerny R: Relevance of miR-2 and miR-143 expression in tissue samples of colorectal carcinoma and its liver metastases. Cancer Genet Cytogenet 2010, 200:154-160.

41. Takamizawa J, Konishi H, Yanagisawa K, Tomida S, Osada H, Endoh H, Harano T, Yatabe Y, Nagino M, Nimura Y, Mitsudomi T, Takahashi T: Reduced expression of the let-7 microRNAs in human lung cancers in association with shortened postoperative survival. Cancer Res 2004, 64:3753-3756

42. Gallardo E, Navarro A, Viñolas N, Marrades RM, Diaz T, Gel B, Quera A, Bandres E, Garcia-Foncillas J, Ramirez J, Monzo M: miR-34a as a prognostic marker of relapse in surgically resected non-small-cell lung cancer. Carcinogenesis 2009, 30:1903-1909.

43. Yu S-L, Chen H-Y, Chang G-C, Chen C-Y, Chen H-W, Singh S, Cheng C-L, YU C-J, Lee Y-C, Chen H-S, Su T-J, Chiang C-C, Li H-N, Hong Q-S, Su H-Y, Chen
C-C, Chen W-J, Liu C-C, Chan W-K, Chen WJ, Li K-C, Chen JJW, Yang P-C: MicroRNA signature predicts survival and relapse in lung cancer. Cancer Cell 2008, 13:48-57.

44. Ma L, Teruya-Feldstein J, Weinberg RA: Tumour invasion and metastasis initiated by microRNA-10b in breast cancer. Nature 2007, 449:682-688.

45. Tavazoie SF, Alarcón C, Oskarsson T, Padua D, Wang Q, Bos PD, Gerald WL, Massagué J: Endogenous human microRNAs that suppress breast cancer metastasis. Nature 2008, 451:147-152

46. Satzger I, Mattern A, Kuettler U, Weinspach D, Voelker B, Kapp A, Gutzmer R: MicroRNA-15b represents an independent prognostic parameter and is correlated with tumor cell proliferation and apoptosis in malignant melanoma. Int J Cancer 2010, 126:2553-2562.

47. Mohri T, Nakajima M, Fukami T, Takamiya M, Aoki Y, Yokoi T: Human CYP2E1 is regulated by miR-378. Biochem Pharmacol 2010, 79:1045-1052.

48. Markou A, Tsaroucha EG, Kaklamanis L, Fotinou M, Georgoulias V, Lianidou ES: Prognostic value of mature microRNA-21 and microRNA-205 overexpression in non-small cell lung cancer by quantitative real-time RT-PCR. Clin Chem 2008, 54:1696-1704.

49. Yang H, Kong W, He L, Zhao J-J, O'Donnell JD, Wang J, Wenham RM, Coppola D, Kruk PA, Nicosia SV, Cheng JQ: MicroRNA expression profiling in human ovarian cancer: miR-214 induces cell survival and cisplatin resistance by targeting PTEN. Cancer Res 2008, 68:425-433.

50. Nagel R, le Sage C, Diosdado B, van der Waal M, Oude Vrielink JAF, Bolijn A, Meijer GA, Agami R: Regulation of the adenomatous polyposis coli gene by the miR-135 family in colorectal cancer. Cancer Res 2008, 68:5795-5802.

51. Johnson SM, Grosshans H, Shingara J, Byrom M, Jarvis R, Cheng A, Labourier E, Reinert KL, Brown D, Slack FJ: RAS is regulated by the let-7 microRNA family. Cell 2005, 120:635-647.

52. Chen X, Guo X, Zhang H, Xiang Y, Chen J, Yin Y, Cai X, Wang K, Wang G, Ba $Y$, Zhu L, Wang J, Yang R, Zhang Y, Ren Z, Zen K, Zhang J, Zhang C-Y: Role of miR-143 targeting KRAS in colorectal tumorigenesis. Oncogene 2009, 28:1385-1392.

53. Guo C, Sah JF, Beard L, Willson JKV, Markowitz SD, Guda K: The noncoding RNA, miR-126, suppresses the growth of neoplastic cells by targeting phosphatidylinositol 3-kinase signaling and is frequently lost in colon cancers. Genes Chromosomes Cancer 2008, 47:939-946.

54. Meng F, Henson R, Wehbe-Janek H, Ghoshal K, Jacob ST, Patel T: MicroRNA21 regulates expression of the PTEN tumor suppressor gene in human hepatocellular cancer. Gastroenterology 2007, 133:647-658.

55. Yu Z, Wang C, Wang M, Li Z, Casimiro MC, Liu M, Wu K, Whittle J, Ju X, Hyslop T, McCue P, Pestell RG: A cyclin D1/microRNA 17/20 regulatory feedback loop in control of breast cancer cell proliferation. J Cell Biol 2008, 182:509-517.

56. Ota A, Tagawa H, Karnan S, Tsuzuki S, Karpas A, Kira S, Yoshida Y, Seto M: Identification and characterization of a novel gene, C13orf25, as a target for 13q31-q32 amplification in malignant lymphoma. Cancer Res 2004 64:3087-3095

57. O'Donnell KA, Wentzel EA, Zeller Kl, Dang CV, Mendell JT: c-Myc-regulated microRNAs modulate E2F1 expression. Nature 2005, 435:839-843.

58. He L, Thomson JM, Hemann MT, Hernando-Monge E, Mu D, Goodson S, Powers S, Cordon-Cardo C, Lowe SW, Hannon GJ, Hammond SM: A microRNA polycistron as a potential human oncogene. Nature 2005 435:828-833.

59. Sakamoto KM: Knocking Down Human Disease: Potential Uses of RNA Interference in Research and Gene Therapy. Pediatric Research 2004, 55:912-913.

60. Noll B, Seiffert S, Vornlocher H-P, Roehl I: Characterization of small interfering RNA by non-denaturing ion-pair reversed-phase liquid chromatography. J Chromatogr A 2011, 1218:5609-5617.

61. Martinez J, Patkaniowska A, Urlaub H, Lührmann R, Tuschl T: Singlestranded antisense siRNAs guide target RNA cleavage in RNAi. Cell 2002 110:563-574.

62. Martinez J, Tuschl T: RISC is a 5' phosphomonoester-producing RNA endonuclease. Genes Dev 2004, 18:975-980.

63. Vassilev LT: Small-molecule antagonists of p53-MDM2 binding: research tools and potential therapeutics. Cell Cycle 2004, 3:419-421.

64. He S-B, Yuan Y, Wang L, Yu M-J, Zhu Y-B, Zhu X-G: Effects of cyclindependent kinase 8 specific siRNA on the proliferation and apoptosis of colon cancer cells. J Exp Clin Cancer Res 2011, 30:109.

65. Durfort T, Tkach M, Meschaninova MI, Rivas MA, Elizalde PV, Venyaminova AG, Schillaci R, François J-C: Small interfering RNA targeted to IGF-IR 
delays tumor growth and induces proinflammatory cytokines in a mouse breast cancer model. PLOS ONE 2012, 7:e29213.

66. Matsubara H, Sakakibara K, Kunimitsu T, Matsuoka H, Kato K, Oyachi N, Dobashi Y, Matsumoto M: Non-small cell lung carcinoma therapy using mTOR-siRNA. Int J Clin Exp Pathol 2012, 5:119-125.

67. He Y, Bi Y, Hua Y, Liu D, Wen S, Wang Q, Li M, Zhu J, Lin T, He D, Li X, Wang $Z$, Wei G: Ultrasound microbubble-mediated delivery of the siRNAs targeting MDR1 reduces drug resistance of yolk sac carcinoma L2 cells. J Exp Clin Cancer Res 2011, 30:104

68. Zhou W, Hu J, Tang H, Wang D, Huang X, He C, Zhu H: Small interfering RNA targeting mcl-1 enhances proteasome inhibitor-induced apoptosis in various solid malignant tumors. BMC Cancer 2011, 11:485.

69. Bansal N, Marchion DC, Bicaku E, Xiong Y, Chen N, Stickles XB, Sawah EA Wenham RM, Apte SM, Gonzalez-Bosquet J, Judson PL, Hakam A, Lancaste JM: BCL2 antagonist of cell death kinases, phosphatases, and ovarian cancer sensitivity to cisplatin. J Gynecol Oncol 2012, 23:35-42.

70. Wang $X$, Chen $Y$, Ren J, Qu X: Small interfering RNA for effective cancer therapies. Mini Rev Med Chem 2011, 11:114-124

71. Costa FF: Non-coding RNAs: Meet thy masters. Bioessays 2010, 32:599-608.

72. Carmell MA, Xuan Z, Zhang MQ, Hannon GJ: The Argonaute family: tentacles that reach into RNAi, developmental control, stem cell maintenance, and tumorigenesis. Genes Dev 2002, 16:2733-2742.

73. Brennecke J, Aravin AA, Stark A, Dus M, Kellis M, Sachidanandam R, Hannon GJ: Discrete small RNA-generating loci as master regulators of transposon activity in Drosophila. Cell 2007, 128:1089-1103.

74. Aravin AA, Lagos-Quintana M, Yalcin A, Zavolan M, Marks D, Snyder B, Gaasterland T, Meyer J, Tuschl T: The small RNA profile during Drosophila melanogaster development. Dev Cell 2003, 5:337-350.

75. Aravin AA, Sachidanandam R, Girard A, Fejes-Toth K, Hannon GJ: Developmentally regulated piRNA clusters implicate MILI in transposon control. Science 2007, 316:744-747.

76. Samji T: PIWI, piRNAs, and Germline Stem Cells: What's the link? Yale J Biol Med 2009, 82:121-124.

77. Thomson T, Lin H: The biogenesis and function of PIWI proteins and piRNAs: progress and prospect. Annu Rev Cell Dev Biol 2009, 25:355-376.

78. Klattenhoff $C$, Theurkauf W: Biogenesis and germline functions of piRNAs Development 2008, 135:3-9.

79. Grochola LF, Greither T, Taubert H, Möller P, Knippschild U, Udelnow A Henne-Bruns D, Würl P: The stem cell-associated Hiwi gene in human adenocarcinoma of the pancreas: expression and risk of tumour-related death. Br J Cancer 2008, 99:1083-1088.

80. Liu X, Sun Y, Guo J, Ma H, Li J, Dong B, Jin G, Zhang J, Wu J, Meng L, Shou $C$ : Expression of hiwi gene in human gastric cancer was associated with proliferation of cancer cells. Int J Cancer 2006, 118:1922-1929.

81. Taubert $H$, Greither T, Kaushal D, Würl P, Bache M, Bartel F, Kehlen A Lautenschläger C, Harris L, Kraemer K, Meye A, Kappler M, Schmidt H, Holzhausen $\mathrm{H}-J$, Hauptmann S: Expression of the stem cell self-renewal gene Hiwi and risk of tumour-related death in patients with soft-tissue sarcoma. Oncogene 2007, 26:1098-1100.

82. Zhao Y-M, Zhou J-M, Wang L-R, He H-W, Wang X-L, Tao Z-H, Sun H-C, Wu W-Z, Fan J, Tang Z-Y, Wang L: HIWI is associated with prognosis in patients with hepatocellular carcinoma after curative resection. Cancer 2012, 118(10):2708-2717.

83. Zeng Y, Qu L, Meng L, Liu C, Dong B, Xing X, Wu J, Shou C: HIWI expression profile in cancer cells and its prognostic value for patients with colorectal cancer. Chin Med J 2011, 124:2144-2149.

84. Sun G, Wang Y, Sun L, Luo H, Liu N, Fu Z, You Y: Clinical significance of Hiwi gene expression in gliomas. Brain Res 2011, 1373:183-188.

85. He W, Wang Z, Wang Q, Fan Q, Shou C, Wang J, Giercksky K-E, Nesland JM, Suo Z: Expression of HIWI in human esophageal squamous cell carcinoma is significantly associated with poorer prognosis. BMC Cancer 2009, 9:426.

86. Lee JH, Schütte D, Wulf G, Füzesi L, Radzun H-J, Schweyer S, Engel W, Nayernia K: Stem-cell protein Piwil2 is widely expressed in tumors and inhibits apoptosis through activation of Stat3/Bcl-XL pathway. Hum Mol Genet 2006, 15:201-211.

87. Lu Y, Zhang K, Li C, Yao Y, Tao D, Liu Y, Zhang S, Ma Y: Piwil2 suppresses p53 by inducing phosphorylation of signal transducer and activator of transcription 3 in tumor cells. PLOS ONE 2012, 7:e30999.

88. Cheng J, Deng $H$, Xiao B, Zhou H, Zhou F, Shen Z, Guo J: piR-823, a novel non-coding small RNA, demonstrates in vitro and in vivo tumor suppressive activity in human gastric cancer cells. Cancer Lett 2012, 315:12-17.

89. Cheng J, Guo J-M, Xiao B-X, Miao Y, Jiang Z, Zhou H, Li Q-N: piRNA, the new non-coding RNA, is aberrantly expressed in human cancer cells. Clin Chim Acta 2011, 412:1621-1625

90. Cui L, Lou Y, Zhang X, Zhou H, Deng H, Song H, Yu X, Xiao B, Wang W, Guo $\mathrm{J}$ : Detection of circulating tumor cells in peripheral blood from patients with gastric cancer using piRNAs as markers. Clin Biochem 2011, 44:10501057.

91. Kiss T: Small nucleolar RNAs: an abundant group of noncoding RNAs with diverse cellular functions. Cell 2002, 109:145-148.

92. Bortolin M-L, Kiss T: Human U19 intron-encoded snoRNA is processed from a long primary transcript that possesses little potential for protein coding. RNA 1998, 4:445-454

93. Weinstein LB, Steitz JA: Guided tours: from precursor snoRNA to functional snoRNP. Curr Opin Cell Biol 1999, 11:378-384.

94. Ganot P, Caizergues-Ferrer M, Kiss T: The Family of Box ACA Small Nucleolar RNAs is Defined by an Evolutionarily Conserved Secondary Structure and Ubiquitous Sequence Elements Essential for RNA Accumulation. Genes Dev 1997, 11:941-956.

95. Vidovic I, Nottrott S, Hartmuth K, Lührmann R, Ficner R: Crystal structure of the spliceosomal $15.5 \mathrm{kD}$ protein bound to a U4 snRNA fragment. $\mathrm{Mol}$ Cell 2000, 6:1331-1342

96. Ender C, Krek A, Friedländer MR, Beitzinger M, Weinmann L, Chen W, Pfeffer S, Rajewsky N, Meister G: A human snoRNA with microRNA-like functions. Mol Cell 2008, 32:519-528.

97. Chang L-S, Lin S-Y, Lieu A-S, Wu T-L: Differential expression of human $5 \mathrm{~S}$ snoRNA genes. Biochemical and Biophysical Research Communications 2002, 299:196-200.

98. Dong X-Y, Rodriguez C, Guo P, Sun X, Talbot JT, Zhou W, Petros J, Li Q, Vessella RL, Kibel AS, Stevens VL, Calle EE, Dong J-T: SnoRNA U50 is a candidate tumor-suppressor gene at $6 q 14.3$ with a mutation associated with clinically significant prostate cancer. Hum Mol Genet 2008, 17:10311042.

99. Dong X-Y, Guo P, Boyd J, Sun X, Li Q, Zhou W, Dong J-T: Implication of snoRNA U50 in human breast cancer. J Genet Genomics 2009, 36:447-454.

100. Tanaka R, Satoh H, Moriyama M, Satoh K, Morishita Y, Yoshida S, Watanabe T, Nakamura Y, Mori S: Intronic U50 small-nucleolar-RNA (snoRNA) host gene of no protein-coding potential is mapped at the chromosome breakpoint $\mathrm{t}(3 ; 6)(\mathrm{q} 27 ; \mathrm{q} 15)$ of human B- cell lymphoma. Genes to Cells 2000, 5:277-287.

101. Mourtada-Maarabouni M, Pickard MR, Hedge VL, Farzaneh F, Williams GT: GAS5, a non-protein-coding RNA, controls apoptosis and is downregulated in breast cancer. Oncogene 2009, 28:195-208.

102. Liao J, Yu L, Mei Y, Guarnera M, Shen J, Li R, Liu Z, Jiang F: Small nucleolar RNA signatures as biomarkers for non-small-cell lung cancer. Mol Cancer 2010, 9:198.

103. Mei Y-P, Liao J-P, Shen J-P, Yu L, Liu B-L, Liu L, Li R-Y, Ji L, Dorsey SG, Jiang Z-R, Katz RL, Wang J-Y, Jiang F: Small nucleolar RNA 42 acts as an oncogene in lung tumorigenesis. Oncogene 2012, 2012, 31(22):2794-2804.

104. Jiang F, Yin Z, Caraway NP, Li R, Katz RL: Genomic profiles in stage primary non small cell lung cancer using comparative genomic hybridization analysis of cDNA microarrays. Neoplasia 2004, 6:623-635.

105. Gebhart E: Double minutes, cytogenetic equivalents of gene amplification, in human neoplasia - a review. Clinical \& translational oncology: official publication of the Federation of Spanish Oncology Societies and of the National Cancer Institute of Mexico 2005, 7:477-485.

106. Gee HE, Buffa FM, Camps C, Ramachandran A, Leek R, Taylor M, Patil M, Sheldon H, Betts G, Homer J, West C, Ragoussis J, Harris AL: The smallnucleolar RNAs commonly used for microRNA normalisation correlate with tumour pathology and prognosis. Br J Cancer 2011, 104:1168-1177.

107. Martens-Uzunova ES, Jalava SE, Dits NF, van Leenders GJLH, Møller S, Trapman J, Bangma CH, Litman T, Visakorpi T, Jenster G: Diagnostic and prognostic signatures from the small non-coding RNA transcriptome in prostate cancer. Oncogene 2012, 31:978-991.

108. Valleron W, Laprevotte E, Gautier E-F, Quelen C, Demur C, Delabesse E, Agirre X, Prósper F, Kiss T, Brousset P: Specific small nucleolar RNA expression profiles in acute leukemia. U.K: Leukemia: Official Journal of the Leukemia Society of America, Leukemia Research Fund; 2012.

109. Preker P, Nielsen J, Kammler S, Lykke-Andersen S, Christensen MS, Mapendano CK, Schierup MH, Jensen TH: RNA exosome depletion reveals 
transcription upstream of active human promoters. Science 2008, 322:1851-1854.

110. Seila AC, Calabrese JM, Levine SS, Yeo GW, Rahl PB, Flynn RA, Young RA, Sharp PA: Divergent transcription from active promoters. Science 2008, 322:1849-1851.

111. Core LJ, Lis JT: Transcription regulation through promoter-proximal pausing of RNA polymerase II. Science 2008, 319:1791-1792.

112. Morris KV, Santoso S, Turner A-M, Pastori C, Hawkins PG: Bidirectional transcription directs both transcriptional gene activation and suppression in human cells. PLOS Genet 2008, 4:e1000258.

113. Schwartz JC, Younger ST, Nguyen N-B, Hardy DB, Monia BP, Corey DR, Janowski BA: Antisense transcripts are targets for activating small RNAs. Nat Struct Mol Biol 2008, 15:842-848.

114. Kapranov P, Cheng J, Dike S, Nix DA, Duttagupta R, Willingham AT, Stadler PF, Hertel J, Hackermüller J, Hofacker IL, Bell I, Cheung E, Drenkow J, Dumais E, Patel S, Helt G, Ganesh M, Ghosh S, Piccolboni A, Sementchenko V, Tammana $\mathrm{H}$, Gingeras TR: RNA maps reveal new RNA classes and a possible function for pervasive transcription. Science 2007, 316:1484-1488.

115. Taft RJ, Kaplan CD, Simons C, Mattick JS: Evolution, biogenesis and function of promoter-associated RNAs. Cell Cycle 2009, 8:2332-2338.

116. Martianov I, Ramadass A, Serra Barros A, Chow N, Akoulitchev A: Repression of the human dihydrofolate reductase gene by a non-coding interfering transcript. Nature 2007, 445:666-670.

117. Han J, Kim D, Morris KV: Promoter-associated RNA is required for RNAdirected transcriptional gene silencing in human cells. Proc Natl Acad Sci USA 2007, 104:12422-12427.

118. Imamura T, Yamamoto S, Ohgane J, Hattori N, Tanaka S, Shiota K: Noncoding RNA directed DNA demethylation of Sphk1 CpG island. Biochem Biophys Res Commun 2004, 322:593-600

119. : Post-transcriptional processing generates a diversity of 5 '-modified long and short RNAs. Nature 2009, 457:1028-1032.

120. Hawkins PG, Santoso S, Adams C, Anest V, Morris KV: Promoter targeted small RNAs induce long-term transcriptional gene silencing in human cells. Nucleic Acids Res 2009, 37:2984-2995.

121. Taft RJ, Hawkins PG, Mattick JS, Morris KV: The relationship between transcription initiation RNAs and CCCTC-binding factor (CTCF) localization. Epigenetics Chromatin 2011, 4:13.

122. Wang X, Arai S, Song X, Reichart D, Du K, Pascual G, Tempst P, Rosenfeld MG, Glass CK, Kurokawa R: Induced ncRNAs allosterically modify RNAbinding proteins in cis to inhibit transcription. Nature 2008, 454:126-130.

123. Watanabe T, Totoki Y, Toyoda A, Kaneda M, Kuramochi-Miyagawa S, Obata Y, Chiba H, Kohara Y, Kono T, Nakano T, Surani MA, Sakaki Y, Sasaki H: Endogenous siRNAs from naturally formed dsRNAs regulate transcripts in mouse oocytes. Nature 2008, 453:539-543.

124. Carone DM, Longo MS, Ferreri GC, Hall L, Harris M, Shook N, Bulazel KV, Carone BR, Obergfell C, O'Neill MJ, O'Neill RJ: A new class of retroviral and satellite encoded small RNAs emanates from mammalian centromeres. Chromosoma 2009, 118:113-125.

125. Bouzinba-Segard H, Guais A, Francastel C: Accumulation of small murine minor satellite transcripts leads to impaired centromeric architecture and function. Proc Natl Acad Sci USA 2006, 103:8709-8714.

126. Valgardsdottir R, Chiodi I, Giordano M, Cobianchi F, Riva S, Biamonti G: Structural and functional characterization of noncoding repetitive RNAs transcribed in stressed human cells. Mol Bio/Cell 2005, 16:2597-2604.

127. Fukagawa T, Nogami M, Yoshikawa M, Ikeno M, Okazaki T, Takami Y, Nakayama T, Oshimura M: Dicer is essential for formation of the heterochromatin structure in vertebrate cells. Nat Cell Biol 2004, 6:784791

128. Cao F, Li X, Hiew S, Brady H, Liu Y, Dou Y: Dicer independent small RNAs associate with telomeric heterochromatin. RNA 2009, 15:1274-1281.

129. Horard B, Gilson E: Telomeric RNA enters the game. Nat Cell Biol 2008, 10:113-115.

130. Meynert A, Birney E: Picking pyknons out of the human genome. Cell 2006, 125:836-838.

131. Rigoutsos I, Huynh T, Miranda K, Tsirigos A, McHardy A, Platt D: Short blocks from the noncoding parts of the human genome have instances within nearly all known genes and relate to biological processes. Proc Natl Acad Sci USA 2006, 103:6605-6610.

132. Glinsky GV: Human genome connectivity code links disease-associated SNPs, microRNAs and pyknons. Cell Cycle 2009, 8:925-930.
133. Tsirigos A, Rigoutsos I: Human and mouse introns are linked to the same processes and functions through each genome's most frequent nonconserved motifs. Nucleic Acids Res 2008, 36:3484-3493.

134. Stabenau A, McVicker G, Melsopp C, Proctor G, Clamp M, Birney E: The Ensembl core software libraries. Genome Res 2004, 14:929-933.

135. Pagano A, Castelnuovo M, Tortelli F, Ferrari R, Dieci G, Cancedda R: New Small Nuclear RNA Gene-Like Transcriptional Units as Sources of Regulatory Transcripts. PLoS Genet 2007, 3:174-184.

136. Guttman M, Amit I, Garber M, French C, Lin MF, Feldser D, Huarte M, Zuk O, Carey BW, Cassady JP, Cabili MN, Jaenisch R, Mikkelsen TS, Jacks T, Hacohen N, Bernstein BE, Kellis M, Regev A, Rinn JL, Lander ES: Chromatin signature reveals over a thousand highly conserved large non-coding RNAs in mammals. Nature 2009, 458:223-227.

137. Chen $Y$, Song $Y$, Wang $Z$, Yue $Z$, Xu H, Xing C, Liu Z: Altered expression of MiR-148a and MiR-152 in gastrointestinal cancers and its clinical significance. J Gastrointest Surg 2010, 14:1170-1179.

138. Lipovich $L$, Johnson R, Lin C-Y: MacroRNA underdogs in a microRNA world: evolutionary, regulatory, and biomedical significance of mammalian long non-protein-coding RNA. Biochim Biophys Acta 2010, 1799:597-615

139. Tripathi V, Ellis JD, Shen Z, Song DY, Pan Q, Watt AT, Freier SM, Bennett CF, Sharma A, Bubulya PA, Blencowe BJ, Prasanth SG, Prasanth KV: The nuclearretained noncoding RNA MALAT1 regulates alternative splicing by modulating SR splicing factor phosphorylation. Mol Cell 2010, 39:925-938.

140. Gupta RA, Shah N, Wang KC, Kim J, Horlings HM, Wong DJ, Tsai M-C, Hung T, Argani P, Rinn JL, Wang Y, Brzoska P, Kong B, Li R, West RB, van de Vijver MJ, Sukumar S, Chang HY: Long non-coding RNA HOTAIR reprograms chromatin state to promote cancer metastasis. Nature 2010, 464:1071-1076.

141. Ørom UA, Derrien T, Beringer M, Gumireddy K, Gardini A, Bussotti G, Lai F, Zytnicki M, Notredame C, Huang Q, Guigo R, Shiekhattar R: Long noncoding RNAs with enhancer-like function in human cells. Cell 2010, 143:46-58.

142. Mattick JS, Amaral PP, Dinger ME, Mercer TR, Mehler MF: RNA regulation of epigenetic processes. Bioessays 2009, 31:51-59.

143. Wang KC, Chang HY: Molecular mechanisms of long noncoding RNAs. Mol Cell 2011, 43:904-914.

144. Ishii N, Ozaki K, Sato H, Mizuno H, Saito S, Takahashi A, Miyamoto Y, Ikegawa S, Kamatani N, Hori M, Saito S, Nakamura Y, Tanaka T: Identification of a novel non-coding RNA, MIAT, that confers risk of myocardial infarction. J Hum Genet 2006, 51:1087-1099.

145. Faghihi MA, Modarresi F, Khalil AM, Wood DE, Sahagan BG, Morgan TE, Finch CE, St Laurent G 3rd, Kenny PJ, Wahlestedt C: Expression of a noncoding RNA is elevated in Alzheimer's disease and drives rapid feedforward regulation of beta-secretase. Nat Med 2008, 14:723-730.

146. Ji P, Diederichs S, Wang W, Böing S, Metzger R, Schneider PM, Tidow N, Brandt B, Buerger H, Bulk E, Thomas M, Berdel WE, Serve H, Müller-Tidow C: MALAT-1, a novel noncoding RNA, and thymosin beta4 predict metastasis and survival in early-stage non-small cell lung cancer. Oncogene 2003, 22:8031-8041.

147. Lin R, Maeda S, Liu C, Karin M, Edgington TS: A large noncoding RNA is a marker for murine hepatocellular carcinomas and a spectrum of human carcinomas. Oncogene 2007, 26:851-858.

148. Davis IJ, Hsi B-L, Arroyo JD, Vargas SO, Yeh YA, Motyckova G, Valencia P, Perez-Atayde AR, Argani P, Ladanyi M, Fletcher JA, Fisher DE: Cloning of an Alpha-TFEB fusion in renal tumors harboring the $t(6 ; 11)(p 21 ; q 13)$ chromosome translocation. Proc Natl Acad Sci USA 2003, 100:6051-6056.

149. Guo F, Li Y, Liu Y, Wang J, Li Y, Li G: Inhibition of metastasis-associated lung adenocarcinoma transcript 1 in CaSki human cervical cancer cells suppresses cell proliferation and invasion. Acta Biochim Biophys Sin (Shanghai) 2010, 42:224-229.

150. Fellenberg J, Bernd L, Delling G, Witte D, Zahlten-Hinguranage A: Prognostic significance of drug-regulated genes in high-grade osteosarcoma. Mod Pathol 2007, 20:1085-1094.

151. Koshimizu T, Fujiwara Y, Sakai N, Shibata K, Tsuchiya H: Oxytocin stimulates expression of a noncoding RNA tumor marker in a human neuroblastoma cell line. Life Sci 2010, 86:455-460.

152. Panzitt K, Tschernatsch MMO, Guelly C, Moustafa T, Stradner M, Strohmaier HM, Buck CR, Denk H, Schroeder R, Trauner M, Zatloukal K: Characterization of HULC, a novel gene with striking up-regulation in hepatocellular carcinoma, as noncoding RNA. Gastroenterology 2007, 132:330-342. 
153. Matouk IJ, Abbasi I, Hochberg A, Galun E, Dweik H, Akkawi M: Highly upregulated in liver cancer noncoding RNA is overexpressed in hepatic colorectal metastasis. Eur J Gastroenterol Hepatol 2009, 21:688-692.

154. Chen W, Böcker W, Brosius J, Tiedge H: Expression of neural BC200 RNA in human tumours. J Pathol 1997, 183:345-351.

155. lacoangeli A, Lin Y, Morley EJ, Muslimov IA, Bianchi R, Reilly J, Weedon J, Diallo R, Böcker W, Tiedge H: BC200 RNA in invasive and preinvasive breast cancer. Carcinogenesis 2004, 25:2125-2133.

156. Brannan Cl, Dees EC, Ingram RS, Tilghman SM: The product of the $\mathrm{H} 19$ gene may function as an RNA. Mol Cell Biol 1990, 10:28-36.

157. Gabory A, Jammes H, Dandolo L: The H19 locus: role of an imprinted noncoding RNA in growth and development. Bioessays 2010, 32:473-480.

158. Hibi K, Nakamura H, Hirai A, Fujikake Y, Kasai Y, Akiyama S, Ito K, Takagi H: Loss of H19 imprinting in esophageal cancer. Cancer Res 1996, 56:480482.

159. Berteaux N, Lottin S, Adriaenssens E, Van Coppenolle F, Van Coppennolle F, Leroy $X_{,}$Coll J, Dugimont T, Curgy J-J: Hormonal regulation of H19 gene expression in prostate epithelial cells. J Endocrinol 2004, 183:69-78.

160. Eis PS, Tam W, Sun L, Chadburn A, Li Z, Gomez MF, Lund E, Dahlberg JE: Accumulation of miR-155 and BIC RNA in human B cell lymphomas. Proc Natl Acad Sci USA 2005, 102:3627-3632.

161. Chung S, Nakagawa H, Uemura M, Piao L, Ashikawa K, Hosono N, Takata R, Akamatsu S, Kawaguchi T, Morizono T, Tsunoda T, Daigo Y, Matsuda K, Kamatani N, Nakamura Y, Kubo M: Association of a novel long non-coding RNA in 8q24 with prostate cancer susceptibility. Cancer Sci 2011, 102:245-252.

162. Pasic I, Shlien A, Durbin AD, Stavropoulos DJ, Baskin B, Ray PN, Novokmet A, Malkin D: Recurrent focal copy-number changes and loss of heterozygosity implicate two noncoding RNAs and one tumor suppressor gene at chromosome 3q13.31 in osteosarcoma. Cancer Res 2010, 70:160-171.

163. Petrovics G, Zhang W, Makarem M, Street JP, Connelly R, Sun L, Sesterhenn IA, Srikantan V, Moul JW, Srivastava S: Elevated expression of PCGEM1, a prostate-specific gene with cell growth-promoting function, is associated with high-risk prostate cancer patients. Oncogene 2004 23:605-611.

164. Srikantan V, Zou Z, Petrovics G, Xu L, Augustus M, Davis L, Livezey JR, Connell T, Sesterhenn IA, Yoshino K, Buzard GS, Mostofi FK, McLeod DG, Moul JW, Srivastava S: PCGEM1, a prostate-specific gene, is overexpressed in prostate cancer. Proc Natl Acad Sci USA 2000, 97:12216-12221.

165. Fu X, Ravindranath L, Tran N, Petrovics G, Srivastava S: Regulation of apoptosis by a prostate-specific and prostate cancer-associated noncoding gene, PCGEM1. DNA Cell Biol 2006, 25:135-141.

166. Wang X-S, Zhang Z, Wang H-C, Cai J-L, Xu Q-W, Li M-Q, Chen Y-C, Qian X-P, Lu T-J, Yu L-Z, Zhang Y, Xin D-Q, Na Y-Q, Chen W-F: Rapid identification of UCA1 as a very sensitive and specific unique marker for human bladder carcinoma. Clin Cancer Res 2006, 12:4851-4858.

167. Bussemakers MJ, van Bokhoven A, Verhaegh GW, Smit FP, Karthaus HF, Schalken JA, Debruyne FM, Ru N, Isaacs WB: DD3: a new prostate-specific gene, highly overexpressed in prostate cancer. Cancer Res 1999, 59:59755979 .

168. de Kok JB, Verhaegh GW, Roelofs RW, Hessels D, Kiemeney LA, Aalders TW, Swinkels DW, Schalken JA: DD3(PCA3), a very sensitive and specific marker to detect prostate tumors. Cancer Res 2002, 62:2695-2698.

169. Korneev SA, Korneeva El, Lagarkova MA, Kiselev SL, Critchley G, O'Shea M: Novel noncoding antisense RNA transcribed from human anti-NOS2A locus is differentially regulated during neuronal differentiation of embryonic stem cells. RNA 2008, 14:2030-2037.

170. Calin GA, Liu C, Ferracin M, Hyslop T, Spizzo R, Sevignani C, Fabbri M, Cimmino A, Lee EJ, Wojcik SE, Shimizu M, Tili E, Rossi S, Taccioli C, Pichiorri F, Liu X, Zupo S, Herlea V, Gramantieri L, Lanza G, Alder H, Rassenti L, Volinia S, Schmittgen TD, Kipps TJ, Negrini M, Croce CM: Ultraconserved regions encoding ncRNAs are altered in human leukemias and carcinomas. Cancer Cell 2007, 12:215-229.

171. Braconi C, Valeri N, Kogure T, Gasparini P, Huang N, Nuovo GJ, Terracciano $\mathrm{L}$, Croce CM, Patel T: Expression and functional role of a transcribed noncoding RNA with an ultraconserved element in hepatocellular carcinoma. Proc Natl Acad Sci USA 2011, 108:786-791.

172. Yu W, Gius D, Onyango P, Muldoon-Jacobs K, Karp J, Feinberg AP, Cui H: Epigenetic silencing of tumour suppressor gene p15 by its antisense RNA. Nature 2008, 451:202-206.
173. Folkersen L, Kyriakou T, Goel A, Peden J, Mälarstig A, Paulsson-Berne G, Hamsten A, Hugh Watkins, Franco-Cereceda A, Gabrielsen A, Eriksson P: Relationship between CAD risk genotype in the chromosome 9p21 locus and gene expression. Identification of eight new ANRIL splice variants. PLOS ONE 2009, 4:e7677.

174. Yap KL, Li S, Muñoz-Cabello AM, Raguz S, Zeng L, Mujtaba S, Gil J, Walsh MJ, Zhou M-M: Molecular interplay of the noncoding RNA ANRIL and methylated histone $\mathrm{H} 3$ lysine 27 by polycomb CBX7 in transcriptional silencing of INK4a. Mol Cell 2010, 38:662-674.

175. Pasmant $E$, Laurendeau I, Héron D, Vidaud M, Vidaud D, Bièche I: Characterization of a germ-line deletion, including the entire INK4/ARF locus, in a melanoma-neural system tumor family: identification of ANRIL, an antisense noncoding RNA whose expression coclusters with ARF. Cancer Res 2007, 67:3963-3969.

176. Miyoshi N, Wagatsuma H, Wakana S, Shiroishi T, Nomura M, Aisaka K, Kohda T, Surani MA, Kaneko-Ishino T, Ishino F: Identification of an imprinted gene, Meg3/Gtl2 and its human homologue MEG3, first mapped on mouse distal chromosome 12 and human chromosome 14q. Genes Cells 2000, 5:211-220.

177. Zhang X, Zhou Y, Mehta KR, Danila DC, Scolavino S, Johnson SR, Klibanski A: A pituitary-derived MEG3 isoform functions as a growth suppressor in tumor cells. J Clin Endocrinol Metab 2003, 88:5119-5126.

178. Zhang X, Rice K, Wang Y, Chen W, Zhong Y, Nakayama Y, Zhou Y, Klibanski A: Maternally expressed gene 3 (MEG3) noncoding ribonucleic acid: isoform structure, expression, and functions. Endocrinology 2010, 151:939-947.

179. Leygue E, Dotzlaw H, Watson PH, Murphy LC: Expression of the steroid receptor RNA activator in human breast tumors. Cancer Res 1999, 59:4190-4193.

180. Chooniedass-Kothari S, Emberley E, Hamedani MK, Troup S, Wang X, Czosnek A, Hube F, Mutawe M, Watson PH, Leygue E: The steroid receptor RNA activator is the first functional RNA encoding a protein. FEBS Lett 2004, 566:43-47.

181. Poliseno L, Salmena L, Zhang J, Carver B, Haveman WJ, Pandolfi PP: A coding-independent function of gene and pseudogene mRNAs regulates tumour biology. Nature 2010, 465:1033-1038.

182. Alimonti A, Carracedo A, Clohessy JG, Trotman LC, Nardella C, Egia A, Salmena L, Sampieri K, Haveman WJ, Brogi E, Richardson AL, Zhang J, Pandolfi PP: Subtle variations in Pten dose determine cancer susceptibility. Nat Genet 2010, 42:454-458.

183. Yu M, Ohira M, Li Y, Niizuma H, Oo ML, Zhu Y, Ozaki T, Isogai E, Nakamura $Y$, Koda T, Oba S, Yu B, Nakagawara A: High expression of ncRAN, a novel non-coding RNA mapped to chromosome 17q25.1, is associated with poor prognosis in neuroblastoma. Int J Oncol 2009, 34:931-938.

184. Zhu Y, Yu M, Li Z, Kong C, Bi J, Li J, Gao Z, Li Z: ncRAN, a newly identified long noncoding RNA, enhances human bladder tumor growth, invasion, and survival. Urology 2011, 77:510. e1-5.

185. Silva JM, Boczek NJ, Berres MW, Ma X, Smith DI: LSINCT5 is over expressed in breast and ovarian cancer and affects cellular proliferation. RNA Biol 2011, 8:496-505.

186. Khalil AM, Guttman M, Huarte M, Garber M, Raj A, Rivea Morales D, Thomas K, Presser A, Bernstein BE, van Oudenaarden A, Regev A, Lander ES, Rinn JL: Many human large intergenic noncoding RNAs associate with chromatin-modifying complexes and affect gene expression. Proc Natl Acad Sci USA 2009, 106:11667-11672.

187. Tsai M-C, Manor O, Wan Y, Mosammaparast N, Wang JK, Lan F, Shi Y, Segal E, Chang HY: Long noncoding RNA as modular scaffold of histone modification complexes. Science 2010, 329:689-693.

188. Yang Z, Zhou L, Wu L-M, Lai M-C, Xie H-Y, Zhang F, Zheng S-S: Overexpression of long non-coding RNA HOTAIR predicts tumor recurrence in hepatocellular carcinoma patients following liver transplantation. Ann Surg Oncol 2011, 18:1243-1250.

189. Huarte M, Guttman M, Feldser D, Garber M, Koziol MJ, Kenzelmann-Broz D, Khalil AM, Zuk O, Amit I, Rabani M, Attardi LD, Regev A, Lander ES, Jacks T, Rinn JL: A large intergenic noncoding RNA induced by p53 mediates global gene repression in the p53 response. Cell 2010, 142:409-419.

190. Louro R, Smirnova AS, Verjovski-Almeida S: Long intronic noncoding RNA transcription: expression noise or expression choice? Genomics 2009 93:291-298

191. Louro R, Nakaya HI, Amaral PP, Festa F, Sogayar MC, da Silva AM, VerjovskiAlmeida S, Reis EM: Androgen responsive intronic non-coding RNAs. BMC Biol 2007, 5:4

192. Cawley S, Bekiranov S, Ng HH, Kapranov P, Sekinger EA, Kampa D, Piccolboni A, Sementchenko V, Cheng J, Williams AJ, Wheeler R, Wong B, 
Drenkow J, Yamanaka M, Patel S, Brubaker S, Tammana H, Helt G, Struhl K, Gingeras TR: Unbiased mapping of transcription factor binding sites along human chromosomes 21 and 22 points to widespread regulation of noncoding RNAs. Cell 2004, 116:499-509.

193. Nakaya HI, Amaral PP, Louro R, Lopes A, Fachel AA, Moreira YB, El-Jundi TA, da Silva AM, Reis EM, Verjovski-Almeida S: Genome mapping and expression analyses of human intronic noncoding RNAs reveal tissuespecific patterns and enrichment in genes related to regulation of transcription. Genome Biol 2007, 8:R43.

194. Dinger ME, Amaral PP, Mercer TR, Pang KC, Bruce SJ, Gardiner BB, AskarianAmiri ME, Ru K, Soldà G, Simons C, Sunkin SM, Crowe ML, Grimmond SM, Perkins AC, Mattick JS: Long noncoding RNAs in mouse embryonic stem cell pluripotency and differentiation. Genome Res 2008, 18:1433-1445.

195. Kravchenko JE, Rogozin IB, Koonin EV, Chumakov PM: Transcription of mammalian messenger RNAs by a nuclear RNA polymerase of mitochondrial origin. Nature 2005, 436:735-739.

196. Li S-C, Tang P, Lin W-C: Intronic microRNA: discovery and biological implications. DNA Cell Biol 2007, 26:195-207.

197. Borchert GM, Lanier W, Davidson BL: RNA polymerase III transcribes human microRNAs. Nat Struct Mol Biol 2006, 13:1097-1101.

198. Massone S, Vassallo I, Castelnuovo M, Fiorino G, Gatta E, Robello M, Borghi R, Tabaton M, Russo C, Dieci G, Cancedda R, Pagano A: RNA polymerase III drives alternative splicing of the potassium channel-interacting protein contributing to brain complexity and neurodegeneration. J Cell Biol 2011, 193:851-866.

199. Massone S, Vassallo I, Fiorino G, Castelnuovo M, Barbieri F, Borghi R, Tabaton M, Robello M, Gatta E, Russo C, Florio T, Dieci G, Cancedda R, Pagano A: $17 \mathrm{~A}$, a novel non-coding RNA, regulates GABA $B$ alternative splicing and signaling in response to inflammatory stimuli and in Alzheimer disease. Neurobiol Dis 2011, 41:308-317.

200. Louro R, El-Jundi T, Nakaya HI, Reis EM, Verjovski-Almeida S: Conserved tissue expression signatures of intronic noncoding RNAs transcribed from human and mouse loci. Genomics 2008, 92:18-25.

201. Rearick D, Prakash A, McSweeny A, Shepard SS, Fedorova L, Fedorov A: Critical association of ncRNA with introns. Nucleic Acids Res 2011, 39:2357-2366.

202. Mercer TR, Dinger ME, Sunkin SM, Mehler MF, Mattick JS: Specific expression of long noncoding RNAs in the mouse brain. Proc Natl Acad Sci USA 2008, 105:716-721.

203. Katayama S, Tomaru Y, Kasukawa T, Waki K, Nakanishi M, Nakamura M, Nishida H, Yap CC, Suzuki M, Kawai J, Suzuki H, Carninci P, Hayashizaki Y, Wells C, Frith M, Ravasi T, Pang KC, Hallinan J, Mattick J, Hume DA, Lipovich L, Batalov S, Engström PG, Mizuno Y, Faghihi MA, Sandelin A, Chalk AM, Mottagui-Tabar S, Liang Z, Lenhard B, Wahlestedt C: Antisense transcription in the mammalian transcriptome. Science 2005, 309:1564-1566.

204. Hirose T, Ideue T, Nagai M, Hagiwara M, Shu M-D, Steitz JA: A spliceosomal intron binding protein, IBP160, links position-dependent assembly of intronencoded box C/D snoRNP to pre-mRNA splicing. Mol Cell 2006, 23:673-684.

205. Filipowicz W, Pogacić V: Biogenesis of small nucleolar ribonucleoproteins. Curr Opin Cell Biol 2002, 14:319-327.

206. Heo JB, Sung S: Vernalization-mediated epigenetic silencing by a long intronic noncoding RNA. Science 2011, 331:76-79.

207. Tahira AC, Kubrusly MS, Faria MF, Dazzani B, Fonseca RS, Maracaja-Coutinho V, Verjovski-Almeida S, Machado MCC, Reis EM: Long noncoding intronic RNAs are differentially expressed in primary and metastatic pancreatic cancer. Mol Cancer 2011, 10:141.

208. Isken O, Maquat LE: Telomeric RNAs as a novel player in telomeric integrity. F1000 Biol Rep 2009, 1:90

209. Azzalin CM, Reichenbach P, Khoriauli L, Giulotto E, Lingner J: Telomeric repeat containing RNA and RNA surveillance factors at mammalian chromosome ends. Science 2007, 318:798-801.

210. Schoeftner S, Blasco MA: Developmentally regulated transcription of mammalian telomeres by DNA-dependent RNA polymerase II. Nat Cell Biol 2008, 10:228-236.

211. Schoeftner S, Blasco MA: A "higher order" of telomere regulation: telomere heterochromatin and telomeric RNAs. EMBO J 2009, 28:2323-2336.

212. Luke B, Panza A, Redon S, Iglesias N, Li Z, Lingner J: The Rat1p 5' to $3^{\prime}$ exonuclease degrades telomeric repeat-containing RNA and promotes telomere elongation in Saccharomyces cerevisiae. Mol Cell 2008, 32:465-477.

213. Caslini C, Connelly JA, Serna A, Broccoli D, Hess JL: MLL associates with telomeres and regulates telomeric repeat-containing RNA transcription. Mol Cell Biol 2009, 29:4519-4526.
214. Sampl S, Pramhas S, Stern C, Preusser M, Marosi C, Holzmann K: Expression of Telomeres in Astrocytoma WHO Grade 2 to 4: TERRA Level Correlates with Telomere Length, Telomerase Activity, and Advanced Clinical Grade. Trans/ Oncol 2012, 5:56-65.

215. Schoeftner S, Blasco MA: Chromatin regulation and non-coding RNAs at mammalian telomeres. Semin Cell Dev Biol 2010, 21:186-193.

216. Ulveling D, Francastel C, Hubé F: When one is better than two: RNA with dual functions. Biochimie 2011, 93:633-644.

217. Lanz RB, McKenna NJ, Onate SA, Albrecht U, Wong J, Tsai SY, Tsai MJ, O'Malley BW: A steroid receptor coactivator, SRA, functions as an RNA and is present in an SRC-1 complex. Cell 1999, 97:17-27.

218. Kawashima H, Takano H, Sugita S, Takahara Y, Sugimura K, Nakatani T: A novel steroid receptor co-activator protein (SRAP) as an alternative form of steroid receptor RNA-activator gene: expression in prostate cancer cells and enhancement of androgen receptor activity. Biochem J 2003, 369:163-171.

219. Xu K, Liang X, Cui D, Wu Y, Shi W, Liu J: miR-1915 inhibits Bcl-2 to modulate multidrug resistance by increasing drug-sensitivity in human colorectal carcinoma cells. Mol Carcinog 2011, doi:10.1002/mc.21832.

220. Hussein-Fikret S, Fuller PJ: Expression of nuclear receptor coregulators in ovarian stromal and epithelial tumours. Mol Cell Endocrinol 2005, 229:149-160.

221. Lanz RB, Chua SS, Barron N, Söder BM, DeMayo F, O'Malley BW: Steroid receptor RNA activator stimulates proliferation as well as apoptosis in vivo. Mol Cell Biol 2003, 23:7163-7176.

222. Harrison PM, Zheng D, Zhang Z, Carriero N, Gerstein M: Transcribed processed pseudogenes in the human genome: an intermediate form of expressed retrosequence lacking protein-coding ability. Nucleic Acids Res 2005, 33:2374-2383.

223. Pink RC, Wicks K, Caley DP, Punch EK, Jacobs L, Carter DRF: Pseudogenes: pseudo-functional or key regulators in health and disease? RNA 2011, 17:792-798.

224. Esnault C, Maestre J, Heidmann T: Human LINE retrotransposons generate processed pseudogenes. Nat Genet 2000, 24:363-367.

225. Terai G, Yoshizawa A, Okida H, Asai K, Mituyama T: Discovery of short pseudogenes derived from messenger RNAs. Nucleic Acids Res 2010, 38:1163-1171.

226. Devor EJ: Primate microRNAs miR-220 and miR-492 lie within processed pseudogenes. J Hered 2006, 97:186-190.

227. Han YJ, Ma SF, Yourek G, Park Y-D, Garcia JGN: A transcribed pseudogene of MYLK promotes cell proliferation. FASEB J 2011, 25:2305-2312.

228. Lu W, Zhou D, Glusman G, Utleg AG, White JT, Nelson PS, Vasicek TJ, Hood $L$, Lin $B: K L K 31 P$ is a novel androgen regulated and transcribed pseudogene of kallikreins that is expressed at lower levels in prostate cancer cells than in normal prostate cells. Prostate 2006, 66:936-944.

229. He L: Posttranscriptional regulation of PTEN dosage by noncoding RNAs. Sci Signal 2010, 3:pe39.

230. Bejerano G, Pheasant M, Makunin I, Stephen S, Kent WJ, Mattick JS, Haussler D: Ultraconserved elements in the human genome. Science 2004, 304:1321-1325.

231. Nobrega MA, Ovcharenko I, Afzal V, Rubin EM: Scanning human gene deserts for long-range enhancers. Science 2003, 302:413.

232. Lujambio A, Portela A, Liz J, Melo SA, Rossi S, Spizzo R, Croce CM, Calin GA Esteller M: CpG island hypermethylation-associated silencing of noncoding RNAs transcribed from ultraconserved regions in human cancer Oncogene 2010, 29:6390-6401.

233. Scaruffi P, Stigliani S, Moretti S, Coco S, De Vecchi C, Valdora F, Garaventa A, Bonassi S, Tonini GP: Transcribed-Ultra Conserved Region expression is associated with outcome in high-risk neuroblastoma. BMC Cancer 2009, 9:441.

234. Mestdagh P, Fredlund E, Pattyn F, Rihani A, Van Maerken T, Vermeulen J, Kumps C, Menten B, De Preter K, Schramm A, Schulte J, Noguera R, Schleiermacher G, Janoueix-Lerosey I, Laureys G, Powel R, Nittner D, Marine J-C, Ringnér M, Speleman F, Vandesompele J: An integrative genomics screen uncovers nCRNA T-UCR functions in neuroblastoma tumours. Oncogene 2010, 29:3583-3592.

235. Yang R, Frank B, Hemminki K, Bartram CR, Wappenschmidt B, Sutter C, Kiechle M, Bugert P, Schmutzler RK, Arnold N, Weber BHF, Niederacher D, Meindl A, Burwinkel B: SNPs in ultraconserved elements and familial breast cancer risk. Carcinogenesis 2008, 29:351-355.

doi:10.1186/1479-5876-10-103

Cite this article as: Sana et al:: Novel classes of non-coding RNAs and cancer. Journal of Translational Medicine 2012 10:103. 